\title{
11. TRACE ELEMENT AND STABLE ISOTOPE GEOCHEMISTRY OF PALEOCENE TO CONIACIAN CARBONATE SAMPLES FROM HOLE 516F, COMPARISON WITH NORTH ATLANTIC AND TETHYS SITES1
}

\author{
Maurice Renard and Gilbert Richebois, Laboratoire de Géologie des Bassins Sédimentaires, \\ Université Pierre et Marie Curie, Paris, France \\ and \\ René Létolle, Laboratoire de Géologie Dynamique, Université Pierre et Marie Curie, Paris, France
}

\begin{abstract}
This paper presents data on trace elements $(\mathrm{Sr}, \mathrm{Mg}, \mathrm{Na}, \mathrm{K}, \mathrm{Mn}, \mathrm{Fe}, \mathrm{Ni}, \mathrm{Cr})$ and isotopes $\left({ }^{13} \mathrm{C},{ }^{18} \mathrm{O}\right)$ on the carbonate fraction of bulk sediments from the Coniacian to Paleocene samples of Hole 516F. Relationships of trace elements to mineralogy and stratigraphic position are discussed at length, with special emphasis on 1) the differences between Hole $516 \mathrm{~F}$ and other oceanic sites, and 2) the transitions observed at the Cretaceous/Tertiary boundary. Isotope data are compared to those obtained in other localities of the same age. The sections show the same major ${ }^{13} \mathrm{C}$ variations at the Cretaceous/Tertiary boundary, indicating that this event is a planetary phenomenon.
\end{abstract}

\section{INTRODUCTION}

Our previous studies in the North Atlantic (DSDP Legs $44,47 \mathrm{~b}, 48$ ) have shown that trace element contents and stable isotope variations of bulk pelagic carbonates are, on a large scale, principally controlled by diagenetic phenomena, but many smaller variations seem to be related to oceanic chemistry fluctuations and could be used as stratigraphic and paleoenvironmental indicators. The purpose of this paper is to test this hypothesis by comparison of trace element and stable isotope variation of bulk carbonates from North Atlantic, South Atlantic, and Tethys sites.

Unless otherwise indicated, core numbers in this paper refer to Hole 516F.

\section{METHODS}

Abundances of strontium, magnesium, sodium, potassium, manganese, iron, nickel, and chromium relative to the carbonate fraction were measured in samples from Hole $516 \mathrm{~F}$. The ages of samples range from Coniacian to Paleocene. After sediments were crushed and washed in distilled water to eliminate contamination by seawater and interstitial waters, they were dissolved in acetic acid. Trace element analysis was carried out by atomic absorption spectrophotometry according to the method described by Renard and Blanc $(1971,1972)$. $\mathrm{X}$-ray diffraction methods revealed a constant carbonate mineralogy, particularly with respect to low-magnesium calcite. The oxygen and carbon isotope techniques used have been described by Létolle et al. (1965). Results from analysis of Eocene samples are given as preliminary data, and all results are summarized in the appendix at the end of the chapter.

\section{RELATIONSHIP BETWEEN TRACE ELEMENT CONTENTS AND INSOLUBLE RESIDUE}

Because the percentage of carbonate is low in the Santonian to Coniacian, early Maestrichtian, and earli-

\footnotetext{
${ }^{1}$ Barker, P. F., Carison, R. L., Johnson, D. A., et al., Init. Repts. DSDP, 72: Washington (U.S. Govt. Printing Office).
}

est Danian sediments at Hole 516F, great caution was exercised to assure that contamination was not introduced by flushing out the insoluble residue (i.e., interlayer cations in clay minerals).

\section{Strontium}

Strontium concentration in Paleocene to early Maestrichtian samples is not correlated with the insoluble residue percentage. A weak correlation appears, however, in Campanian and chiefly Santonian sediments. For samples in which the insoluble proportion is greater than $50 \%$, the carbonate results are unreliable (Fig. 1A).

\section{Magnesium}

Magnesium can be flushed out of clay minerals even if the clay mineral content is low. Consequently we shall consider ony magnesium values lower than or equal to $4000 \mathrm{ppm}$ as significant (Fig. 1B).

\section{Sodium}

The plot of sodium concentration versus percent carbonate indicates no relationship with the clay mineral content, except for Santonian/Coniacian sediments; the same pattern was shown for strontium (Fig. 1C).

\section{Potassium}

There is a very strong positive relationship between potassium and clay mineral content; only Paleocene samples do not fit this pattern (Fig. 1D). It is illusive, however, to insist on using potassium content variations as a paleoenvironment indicator. Only concentrations less than $300 \mathrm{ppm}$ will be used to compare potassium variations with those relative to other elements.

\section{Manganese}

There is no relationship between manganese and insoluble contents (Fig. 2A). 

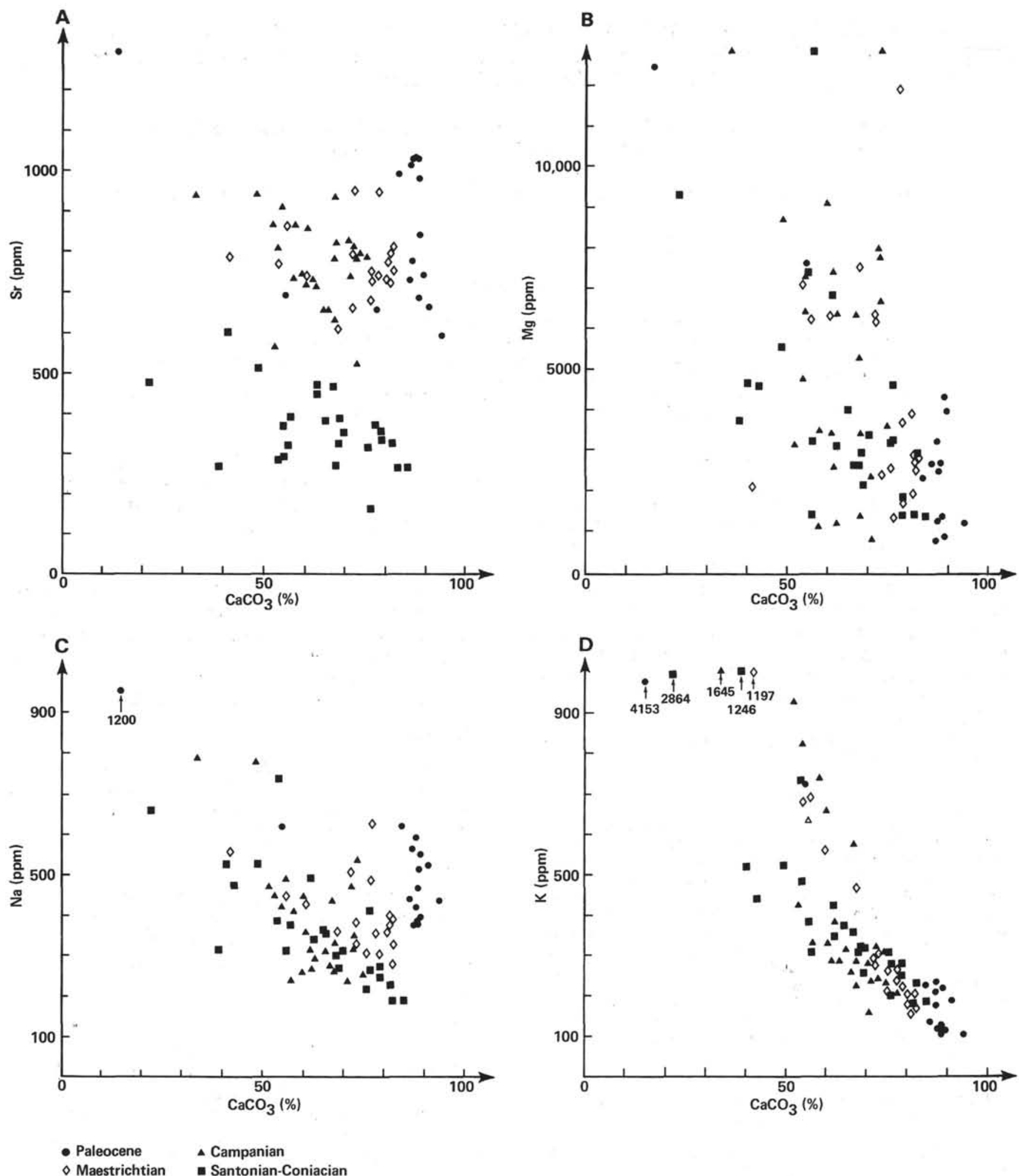

Figure 1. Relationship between trace element concentration and insoluble residue percentage after acetic acid dissolution. A, strontium; B, magnesium; C, sodium; D, potassium. 

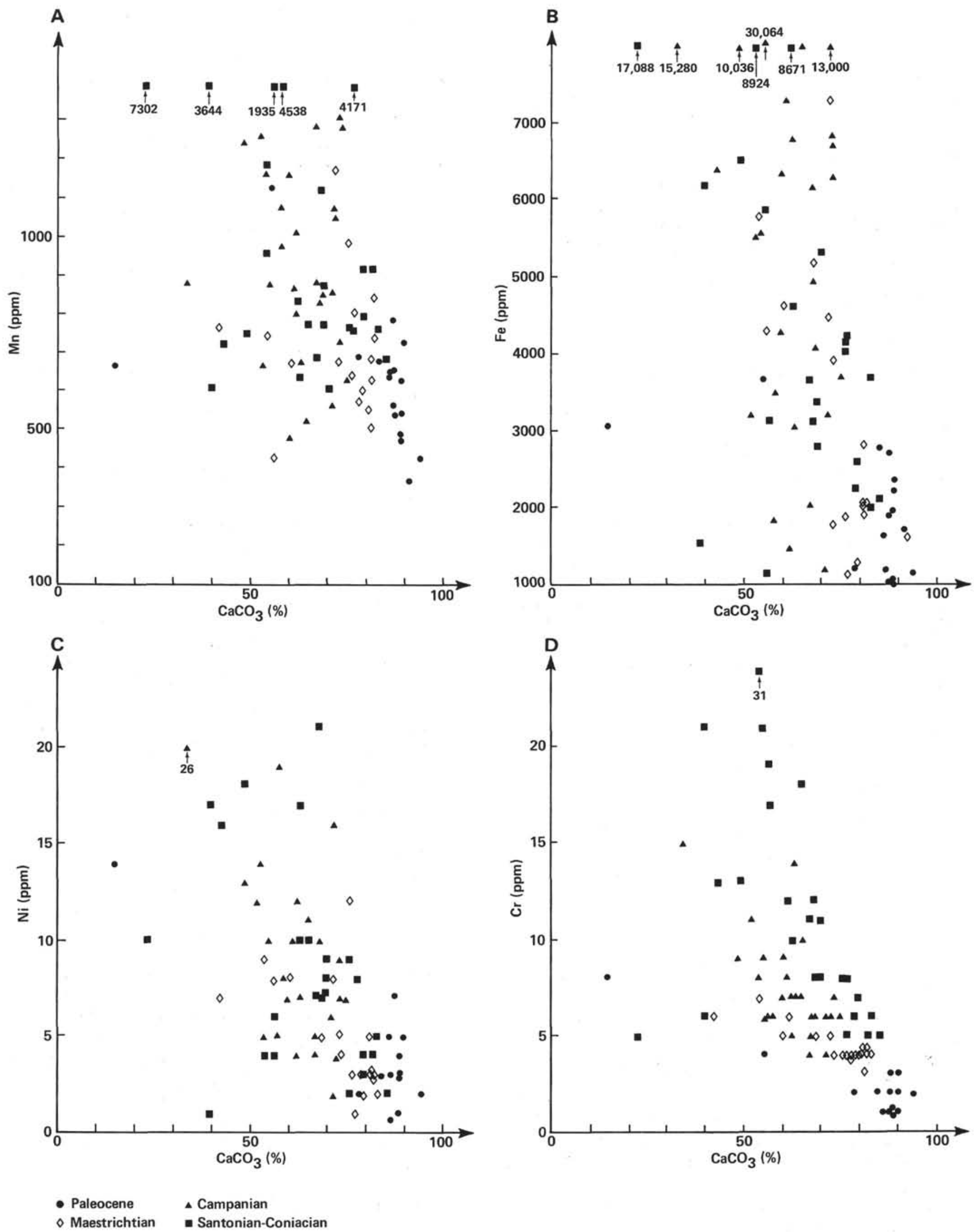

Figure 2. Relationship between trace element concentration and insoluble residue percentage after acetic acid dissolution. A, manganese; B, iron; C, nickel; D, chromium. 


\section{Iron}

There is a weak correlation between iron concentration and percent carbonate; the relationship is stronger for Maestrichtian and Santonian samples (Fig. 2B). Iron is in part carried by clay minerals.

\section{Nickel, Chromium}

Nickel and chromium are related to the insoluble residue percentage, but it seems that for one clay mineral content, different age samples show different concentrations of these trace elements (Fig. 2C and D).

\section{TRACE ELEMENT DISTRIBUTION IN PALEOCENE-CONIACIAN CORES}

\section{Strontium}

Strontium decreases with increasing sediment age; high values ( $\cong 1000 \mathrm{ppm}$ ) for Paleocene samples (Cores 83 to 86 ) change to low values (200-300 ppm) for Santonian-Coniacian samples (Cores 115 to 125) (Fig. 3). This trend has already been observed for DSDP Holes 116, $305,391,398 \mathrm{D}$, and $400 \mathrm{~A}$, and is related to increasing effects of diagenesis (Renard et al., 1978, 1979a,b). Sample age, residence time in a given diagenesis environment, seems to exert a stronger control on this diagenesis than does depth-in-hole, overloading of sediments (Renard, 1979). In this curve, however, the strontium content fluctuation with depth or with age is not regular, and we think that these irregularities are caused by variations in the oceanic environment (salinity, temperature, strontium/calcium ratio) or in biochemical fractionation.

\section{Sodium}

Although the sodium curve variations are less clear, they are similar to those of strontium, with high values (400-500 ppm) for Paleocene samples and low values (200-300 ppm) for Santonian-Coniacian samples (Fig. 4). The sodium content decrease is located approximately at the same sub-bottom depth (Cores 105 to 106). The strontium-sodium correlation graph shows a moderate positive correlation and a good separation of data from different stages (Fig. 5).

\section{Magnesium}

The magnesium curve (Fig. 6) does not show clear variations in the Paleocene to Coniacian cores, probably because of the flushing out of magnesium from the argillaceous part of the samples and the presence of some traces of dolomite in Paleocene sediments. New analyses (Renard, unpublished data) show an increase of $\mathrm{Mg}$ from top to bottom of the core (Oligocene 1000-1500 ppm, Eocene, 1500-2000 ppm, Paleocene 1500-4000 ppm). The strontium content changes in the opposite way (Oligocene 1600-1200 ppm, Eocene 1300-700 ppm, Paleocene $1000-600 \mathrm{ppm}$ ). This reverse behavior of magnesium and strontium, which has already been observed in Sites 116 and 305, and Gubbio outcrops (Italy), seems to be the typical diagenetic chemistry of pelagic carbonates (Renard, 1979). One can compare the trends of strontium and magnesium contents in the sediments with changes of the interstitial waters (Gieskes et al., this volume). The analysis of relationship between trace element contents of interstitial waters and sediments can be found in Renard (1979) and Baker and others (1982).

\section{Manganese}

The manganese curve indicates low values (lower than $1000 \mathrm{ppm}$ ) for almost the length of the core; there is a slight rise in upper Campanian and lower Maestrichtian sediments. An increase to values higher than 3000 ppm occurs beneath Core 121 (Fig. 7). These high manganese values are probably the result of the direct influence of basalt or hydrothermal emanations through sediments from the basaltic oceanic floor.

\section{Iron}

The iron curve shows a great variability, and it is difficult to see a general trend in sub-bottom depth (Fig. 8). Nevertheless, the highest values occur near the bottom of the core. The behavior of iron seems more random than that of manganese, because of the mixed origin of iron, which is either derived from continental erosion and oceanic hydrothermal activity or contained in clay minerals.

\section{TRACE ELEMENTS AT THE CRETACEOUS/ TERTIARY BOUNDARY}

Figures 9 and 10 represent, in a more detailed way, trace element concentrations across the Cretaceous/Tertiary boundary. Whereas the major portion of Paleocene samples are characterized by high and stable carbonate contents (about $90 \% \mathrm{CaCO}_{3}$ ), the first levels of the Tertiary are very impoverished. Maestrichtian and Campanian samples are moderately carbonate rich (60$70 \%$ ), but contents always remain lower and, above all, more irregular than during the Tertiary.

The boundary is well indicated for strontium. Most striking is the reduced strontium content within the lower Paleocene (Figs. 3 and 9). Content for the Maestrichtian strontium levels are lower than those of upper $\mathrm{Pa}$ leocene. A second strontium minimum seems to be located in the middle part of lower Maestrichtian.

For magnesium, the boundary is not particularly obvious, partly because low carbonate content compels us to reject the values corresponding to the lowest Paleocene levels (Figs. 6 and 9). In other sites, such as Gubbio outcrops where carbonate sedimentation is more constant, a magnesium peak related to an early lithification of the first Paleocene abundance marks the Cretaceous/ Tertiary boundary (Renard, 1979). In general, the trends of strontium and magnesium are opposite diagenetic phenomena. In certain restricted parts of the hole, however, strontium and magnesium fluctuate in the same way, and these covariations may be explained in terms of oceanic paleoenvironment variations. The Danian and the middle part of the Maestrichtian are zones with both low strontium and magnesium contents. In the upper Maestrichtian, the same tendency to lower strontium and magnesium contents is apparent.

The sodium curve shows low contents within the uppermost Maestrichtian and lower Paleocene compared to the lower Maestrichtian and upper Paleocene. The 


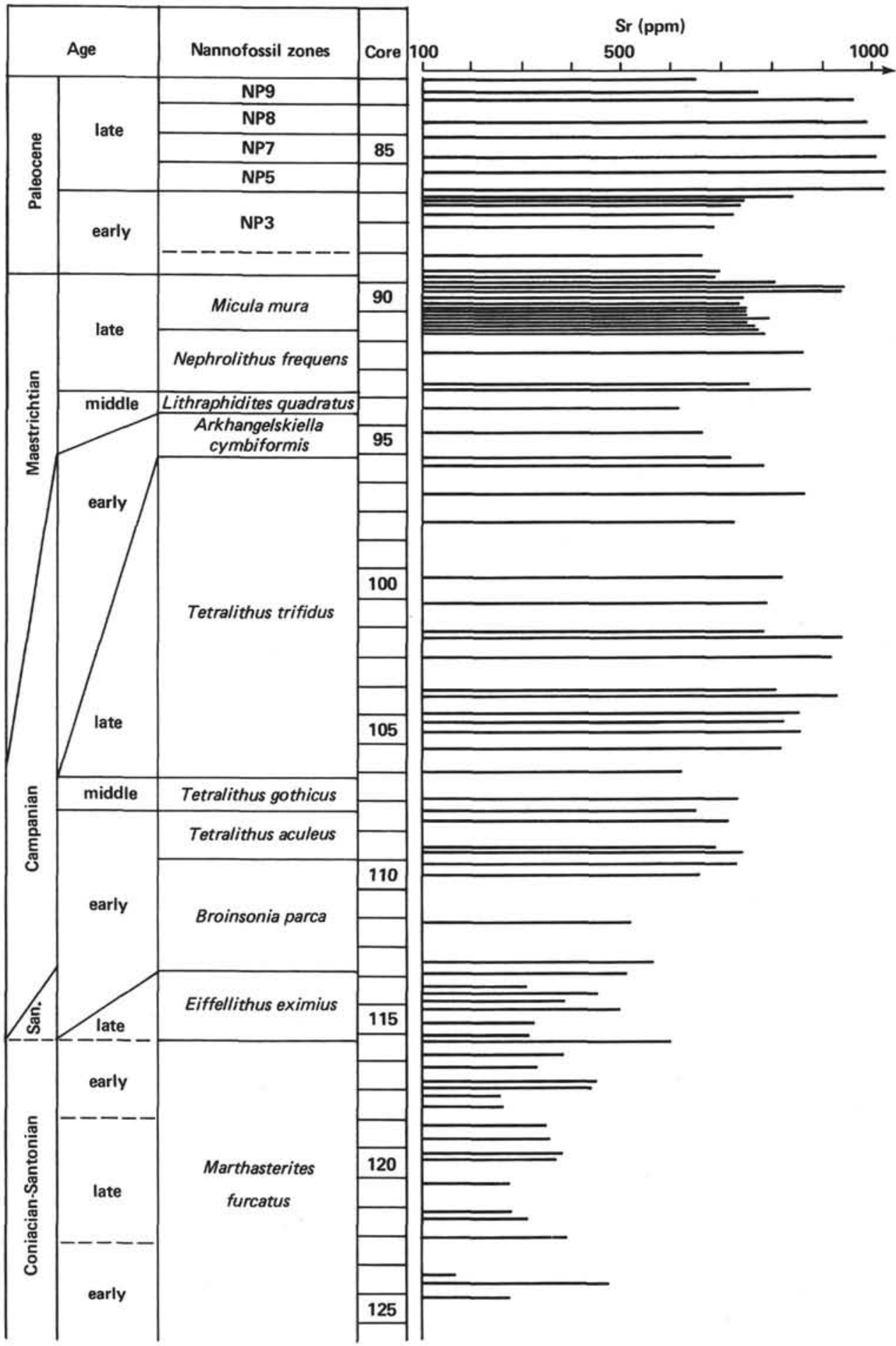

Figure 3. Carbonate strontium content variation in Coniacian-Paleocene cores from Hole 516F.

high value of the first Paleocene level is, doubtless, an artifact caused by a maximum in the clay mineral content (Figs. 4 and 9).

Low potassium content in the Paleocene samples contrasts with the high content in the Cretaceous, but this is a reflection of the difference in the concentration of clay between the Paleocene and the Cretaceous sediments (Fig. 9).

Manganese, iron, nickel, and chromium curves show peak values at the Cretaceous/Tertiary transition zone (Fig. 10). These maxima cannot be explained by clay mineral content variations alone. 


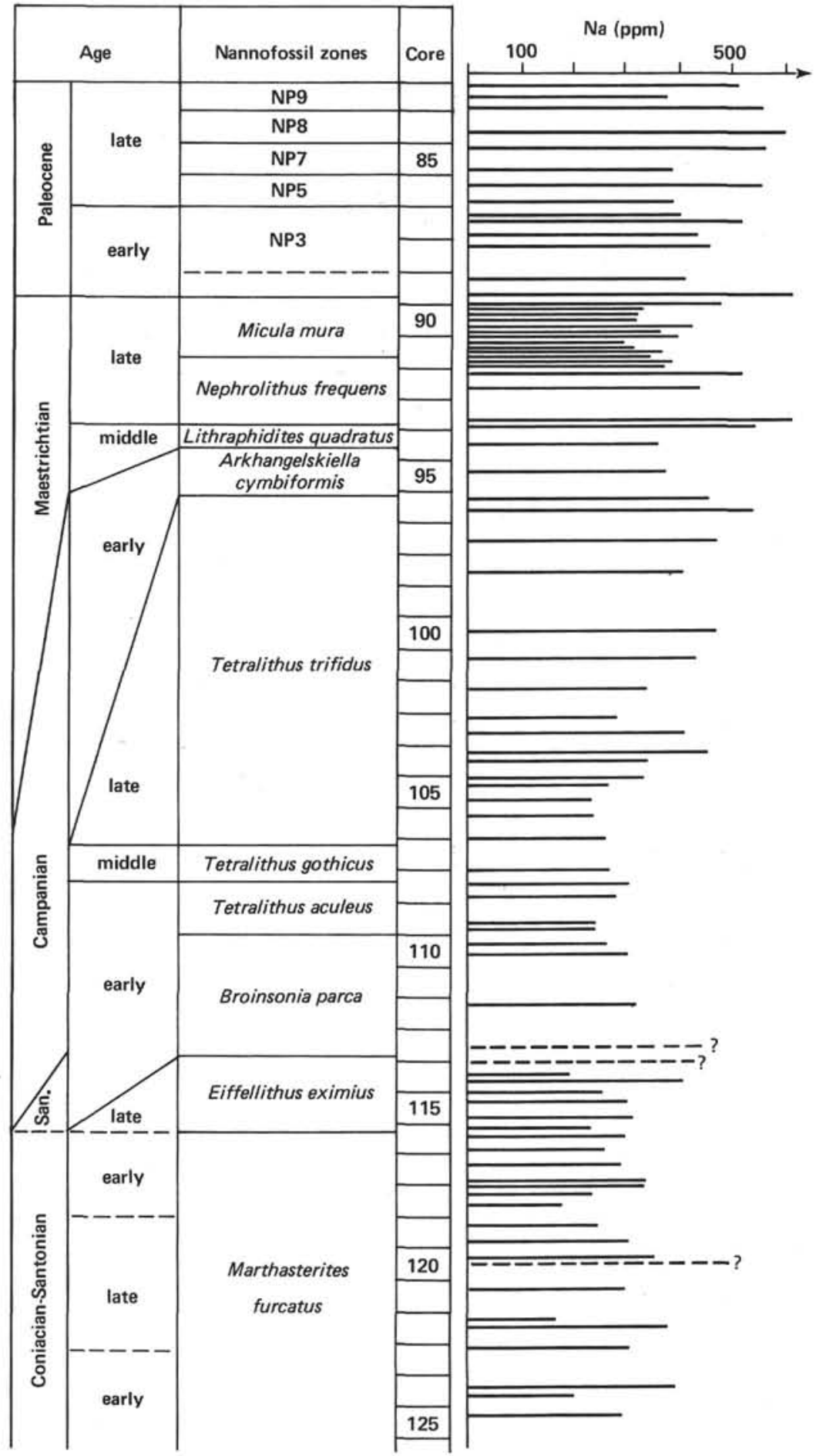

Figure 4. Carbonate sodium content variation in Coniacian-Paleocene cores from Hole $516 \mathrm{~F}$.

\section{COMPARISON BETWEEN THE STRONTIUM CONTENT OF PALEOCENE-CONIACIAN CARBONATES FROM VARIOUS SITES}

A comparison of strontium content and sediment age for North Atlantic Holes 116, 390, 390A, 398D, and 400A (Renard et al., 1978; Renard, 1979; Renard, Létolle, and Richebois, 1979; Renard, Richebois, and Létolle, 1979); the Tethys site represented in the Gubbio outcrop in Italy (Renard, 1979); South Atlantic Hole 516F (this work); and Pacific Sites 305 and 306 (Matter et al., 1975) show the potential use of these element variations as a stratigraphic tool. A number of strontium content variations occur at the same stratigraphic location at these various sites (Fig. 11). For example:

1) Three samples suggest a strontium content increase close to NP10/NP9 zonal boundary in Hole $516 \mathrm{~F}$, and two samples from Hole 398D suggest a similar trend 


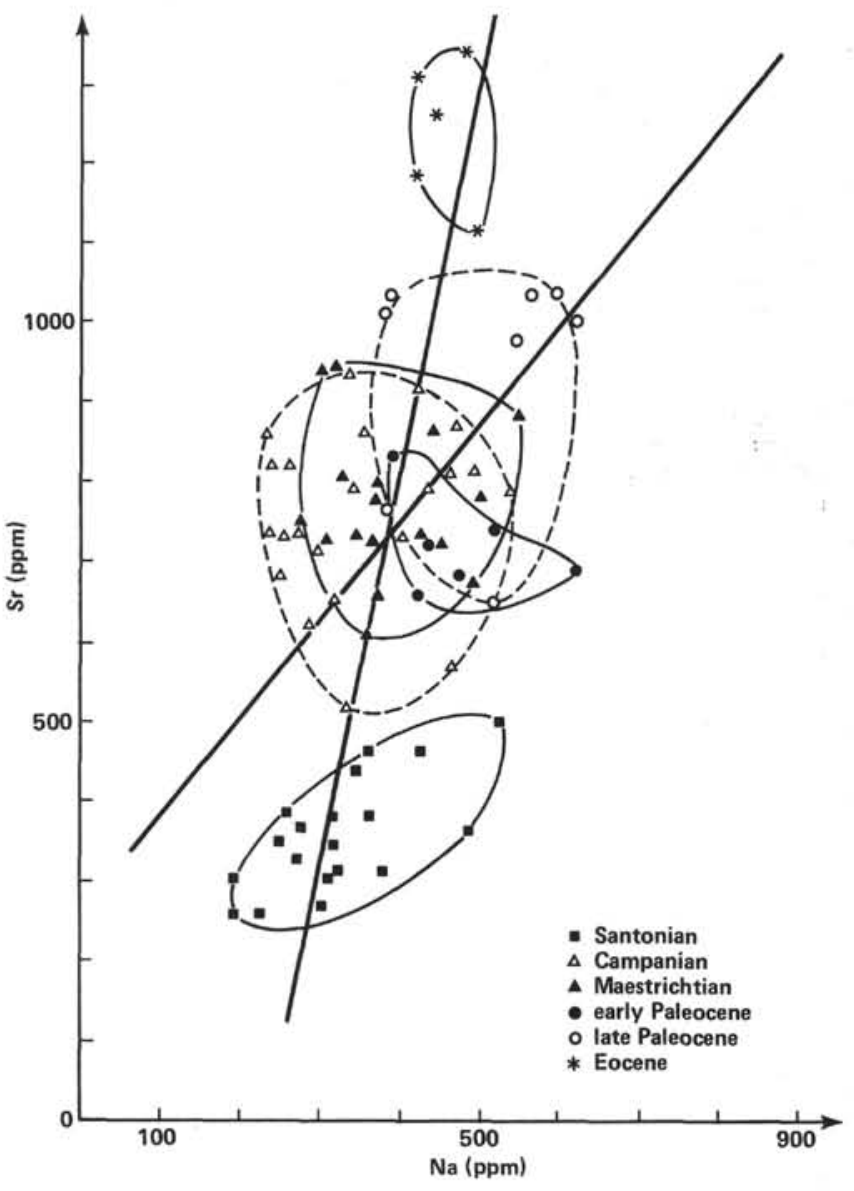

Figure 5. Relationship between strontium and sodium concentrations in Hole 516F.

may occur there. That increase is clearly indicated in the denser sample coverage from Gubbio section.

2) Strontium values are high from the bottom of the NP9 to the NP5 zones in Hole 516F, at Gubbio, and in Hole 398D.

3) Values decrease within Zones NP5 and NP4 in Hole 516F. At Gubbio, this decrease seems to be located at the NP6/NP5 boundary.

4) Strontium content is relatively low within Zones NP3 and NP4 at all four sites.

5) A slight increase of strontium content may be located at the NP3/NP2 zonal boundary in Hole 390 and at Gubbio.

6) Strontium concentrations are relatively low within Zone NP1 in Hole 398D and at Gubbio.

7) Values remain at a relatively high and stable level during Maestrichtian at all four sites and during the Campanian at Gubbio. Maximal values occur during the Micula mura and Nephrolithus frequens zones at Gubbio, and Holes 390A, 392, and 398D.

8) Strontium content decreases within the Santonian, but it seems that this phenomenon begins earlier in Hole 516F (during Broinsonia Parca Zone or even earlier during Tetralithus trifidus Zone) than at Gubbio where it starts only in the middle part of Eiffelithus eximius Zone.

At the present time, the real meaning of these variations is not very clear; they may be caused by salinity, temperature, or oceanic strontium/calcium ratio variations or by variation of strontium metabolism (biochemical fractionation or discrimination for or against strontium relative to calcium) between various species of calcareous nannoplankton and planktonic foraminifers. Whatever the cause of the strontium variations, the apparent synchronism of strontium variations in numerous oceanic sites indicates that these variations are worldwide oceanic phenomena.

We should mention the difficulties inherent in stratigraphic correlations between the four sections. For example, the zones in the Gubbio sequence were established on the basis of planktonic foraminifers, whereas those in Hole $516 \mathrm{~F}$ were based on planktonic foraminifers in the Paleocene and calcareous nannoplankton in the Cretaceous. As a result, the relative location of samples from different sites is somewhat arbitrary.

\section{STRONTIUM CONTENT AND PALE- OCEANOGRAPHIC RECONSTRUCTION}

Figure 12 shows strontium content variation curves in relation to sediment age from each of the various sites under study. The general trend of curves, high values for recent sediments and low values for ancient sediments, is almost certainly related to increasing diagenesis with age (Renard, 1979). Short-term variations, as described above, reflect periodic fluctuations and crises within the oceanic realm.

Two groups of curves can be distinguished: those for North Atlantic Holes 116, 398, and 400A, and those for Tethys, South Atlantic, and Pacific sites (Gubbio and Holes $516 \mathrm{~F}, 305$, and 306). Site 390 is more complicated because the Cretaceous part of the strontium curve is close to values for the North Atlantic group whereas the Paleocene-Eocene part of strontium curve is close to the second group. Strontium contents differ between the two groups by about 200 ppm for Cretaceous carbonates and more for Tertiary carbonates. Originally, we invoked a diagenetic effect to explain this difference between poorly consolidated carbonates of the North Atlantic Ocean and the lithified limestones at Gubbio (Odin et al., 1982). The present work produces proof to the contrary; Gubbio limestones and 516F sediments have the same content of strontium. Latest vadose diagenesis does not play a prominent part in the strontium distribution in pelagic carbonates. Accordingly, the difference between North Atlantic carbonates and the others reflects different oceanic conditions that have prevailed in that basin compared to conditions in the Tethys, South Atlantic, and Pacific. As it will appear later with the isotopic study, it seems that North Atlantic-Tethys communication was very restricted during the Coniacian to Thanetian, whereas circulation between the Tethys and South Atlantic was open. Considering the sites' paleolocations and oceanic paleocirculations (Fig. 13), it is not surprising to find that South Atlantic influences reach Site 390 earlier than the North Atlantic sites.

The strontium content of a precipitated calcite can be described by the expression:

$$
\left[\mathrm{mSr}^{++} / \mathrm{mCa}^{++}\right]_{\text {calcite }}=\mathrm{K}_{\mathrm{Sr}}^{\mathrm{C}}\left[\mathrm{mSr}^{++} / \mathrm{mCa}^{++}\right]_{\text {seawater }} \text {. }
$$




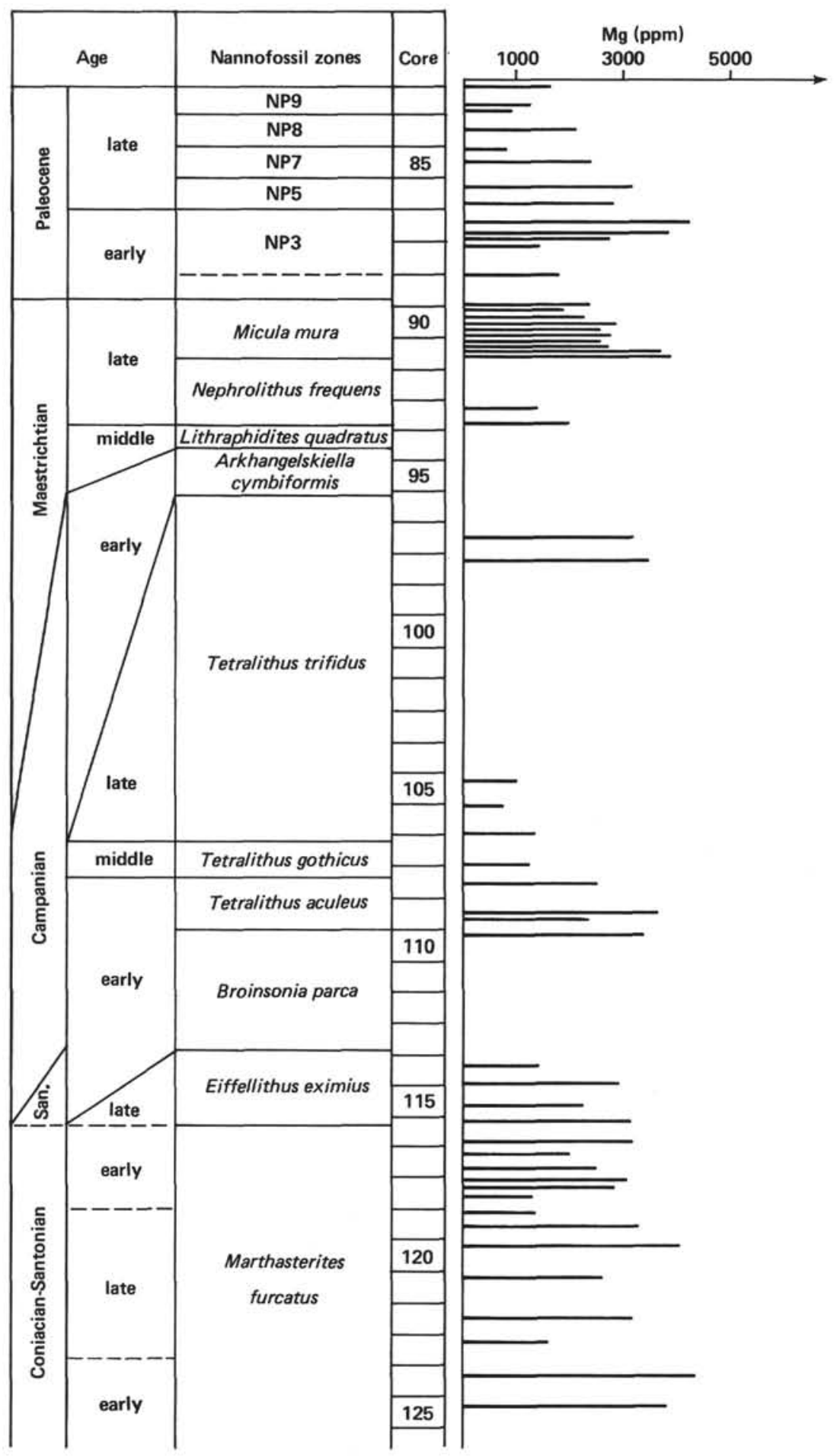

Figure 6. Distribution curve for magnesium concentration in Coniacian-Paleocene cores from Hole $516 \mathrm{~F}$.

The distribution coefficient $\mathrm{K}_{\mathrm{S} r}^{\mathrm{C}}$ decreases linearly with increasing temperature from approximately 0.14 at $25^{\circ} \mathrm{C}$ to about 0.08 at $100^{\circ} \mathrm{C}$ (Kinsman, 1969), leading to the expression:

$$
\mathrm{K}_{\mathrm{Sr}}^{\mathrm{C}} \cong-0.0008 \mathrm{Tp}+0.16
$$

Using the oxygen-isotope-derived (see later) temperature
(Tp) difference of $10^{\circ}$ between Tethys and North Atlantic seawater, one computes:

$$
\Delta \mathrm{K}_{\mathrm{Sr}}^{\mathrm{C}}=0.008 \text { when } \quad \Delta \mathrm{Tp} \text { is } 10^{\circ} .
$$

Strontium determinations in seawater are quite variable, and the result depends heavily on the analytic procedure. At the present time, it is very difficult to get an overall 


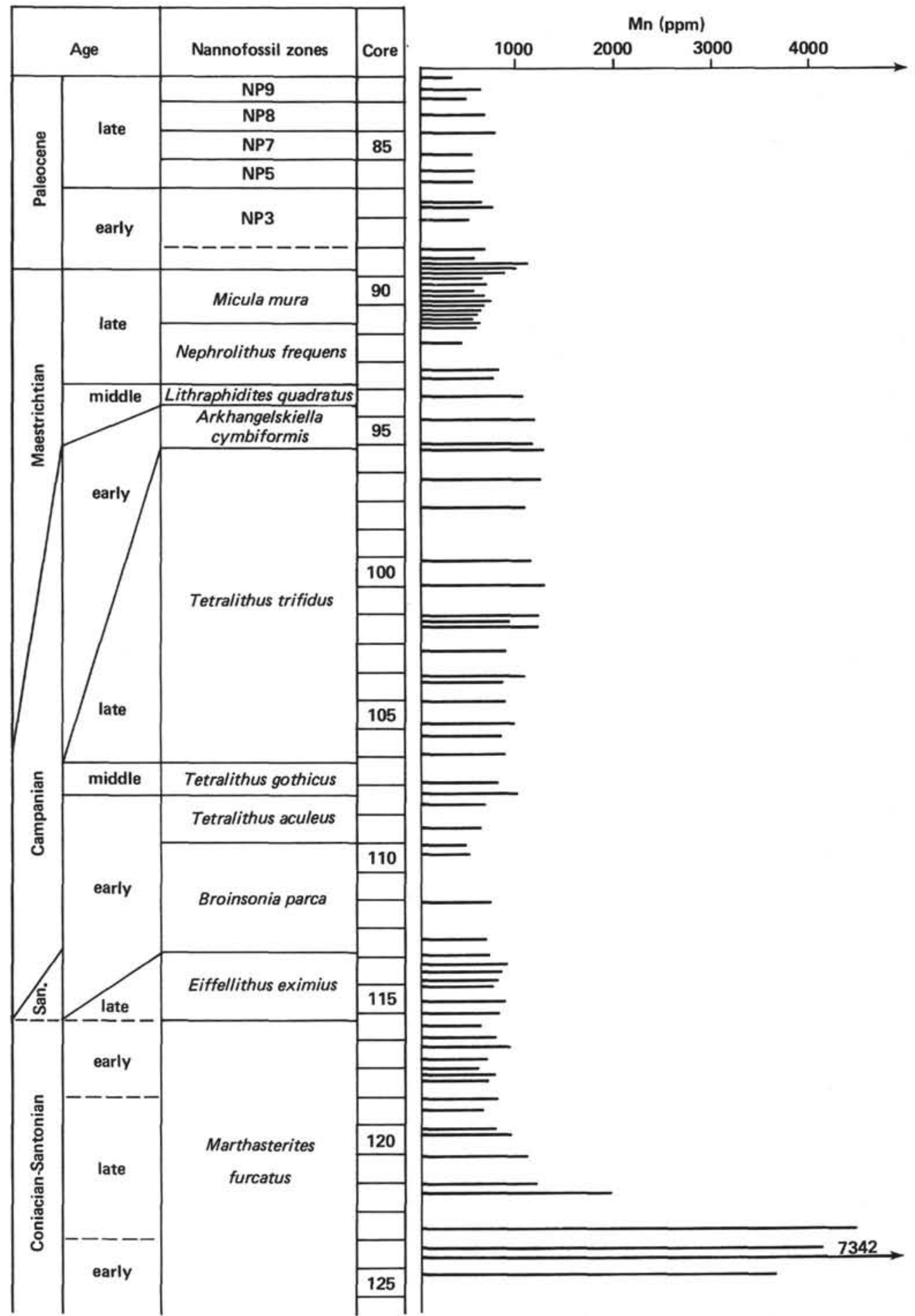

Figure 7. Distribution curve for manganese concentration in Coniacian-Paleocene cores from Hole 516F.

idea of strontium concentrations and variations in seawater (Renard, in preparation). However, if one takes the most commonly accepted value of $\mathrm{Sr} / \mathrm{Ca}$ ratio in seawater $\left(0.86 \pm 0.04 \times 10^{-2}\right.$; Kinsman, 1969), a $\Delta \mathrm{Tp}$ of $10^{\circ}$ leads to:

$[\Delta \mathrm{Sr} / 87.63] /[400,000 / 40.08]=0.008 \times 0.86 \times 10^{-2}$.
From this, one may conclude that a $\Delta \mathrm{Tp}$ of $10^{\circ}$ includes a $\Delta \mathrm{Sr}$ of about $60 \mathrm{ppm}$, and a $\Delta \mathrm{Sr}$ of $200 \mathrm{ppm}$ requires a $\Delta \mathrm{K}_{\mathrm{Sr}}^{\mathrm{C}}$ of 0.0265 , which leads to a $\Delta \mathrm{Tp}$ of about $33^{\circ}$. Thus, the difference of $200 \mathrm{ppm}$ observed between the North Atlantic carbonate strontium content and those of the other oceans cannot be explained by temperature alone. Yet, one must moderate this conclusion because 


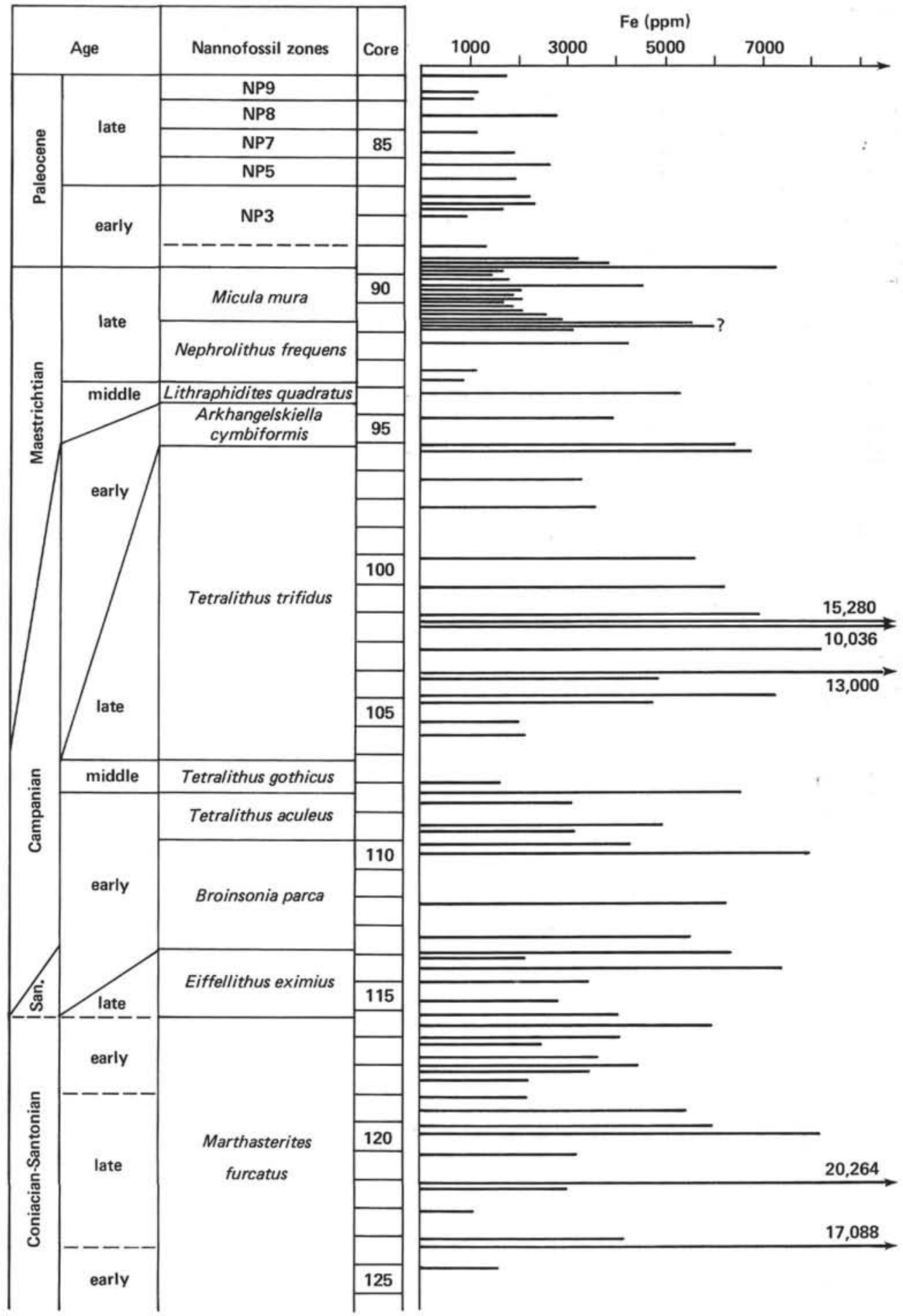

Figure 8. Distribution curve for iron concentration in Coniacian-Paleocene cores from Hole 516F.

the equation defining $\mathrm{K}_{\mathrm{S}_{\mathrm{r}}}^{\mathrm{C}}$ was established on inorganic carbonate precipitation data. It is not known if this equation is applicable in the form given above to organic carbonates produced by planktonic foraminifers and by nannoplankton, especially because it is not known if these organisms biochemically fractionate strontium during their skeletogenesis (Lorens, 1978; Renard, 1979). As a result of fractionation, strontium concentration would depend on the different behavior of foraminifers and nannoplankton living in the North Atlantic Ocean compared to those living in the Tethys, South Atlantic, and Pacific. Perhaps, over and above the thermal explanation, there was also a variation of the $\mathrm{Sr} / \mathrm{Ca}$ ratio between North Atlantic seawater and the seawater of other oceans. Even if local conditions, such as strontium storage by evaporitic deposits in marginal basins, could be found for the South Atlantic Ocean and for the Tethys, it could probably not be extended to the Pacific Ocean. 


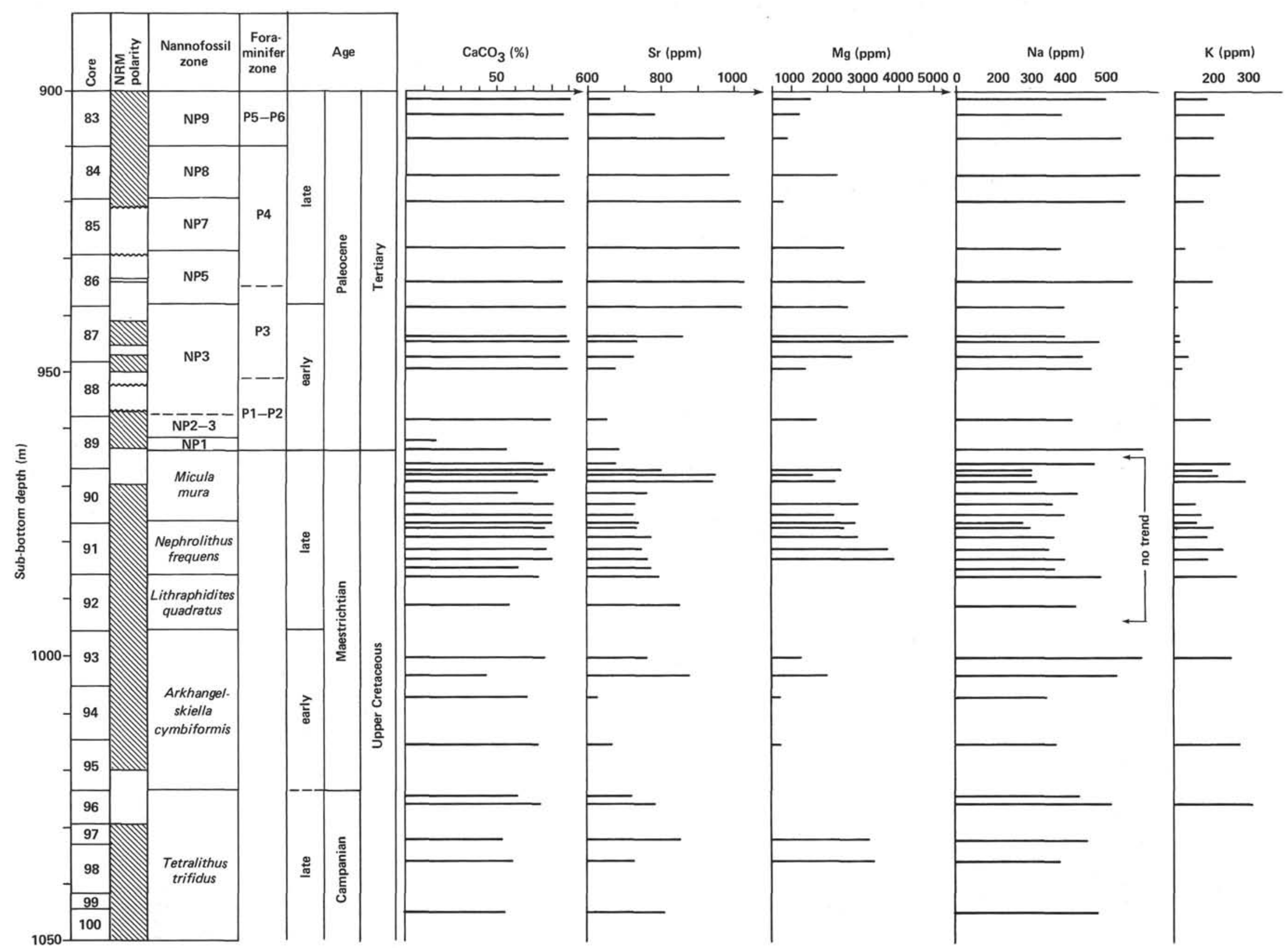

f Figure 9. Calcium carbonate, strontium, magnesium, sodium, and potassium concentration variations during the Cretaceous/Tertiary transition (Hole 516F). 


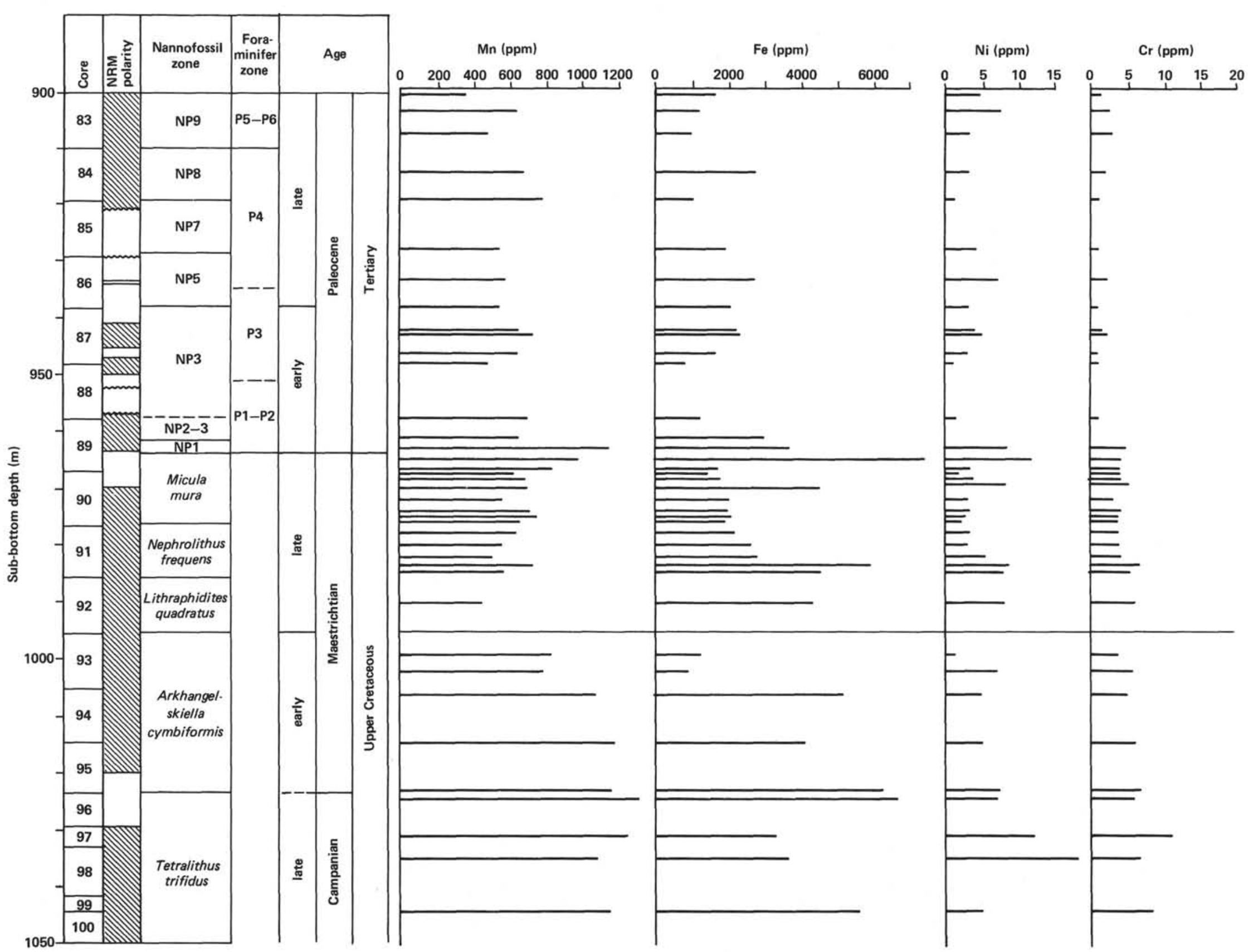




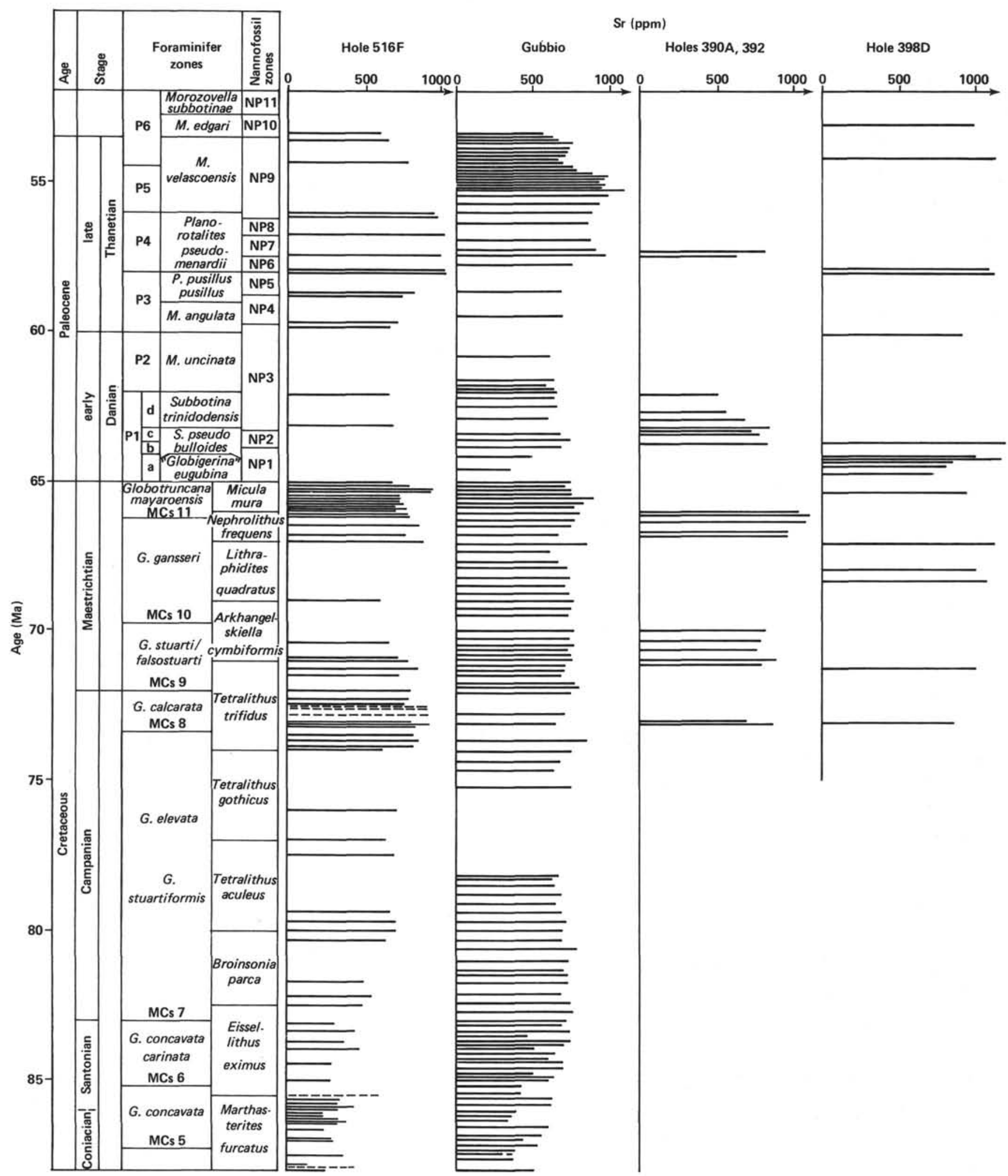

Figure 11. Strontium concentration for sites in the North Atlantic (Holes 390A, 392, and 398D), Tethys (Gubbio, Italy), and South Atlantic (Hole $516 \mathrm{~F}) . \mathrm{NRM}=$ natural remanent magnetization. 


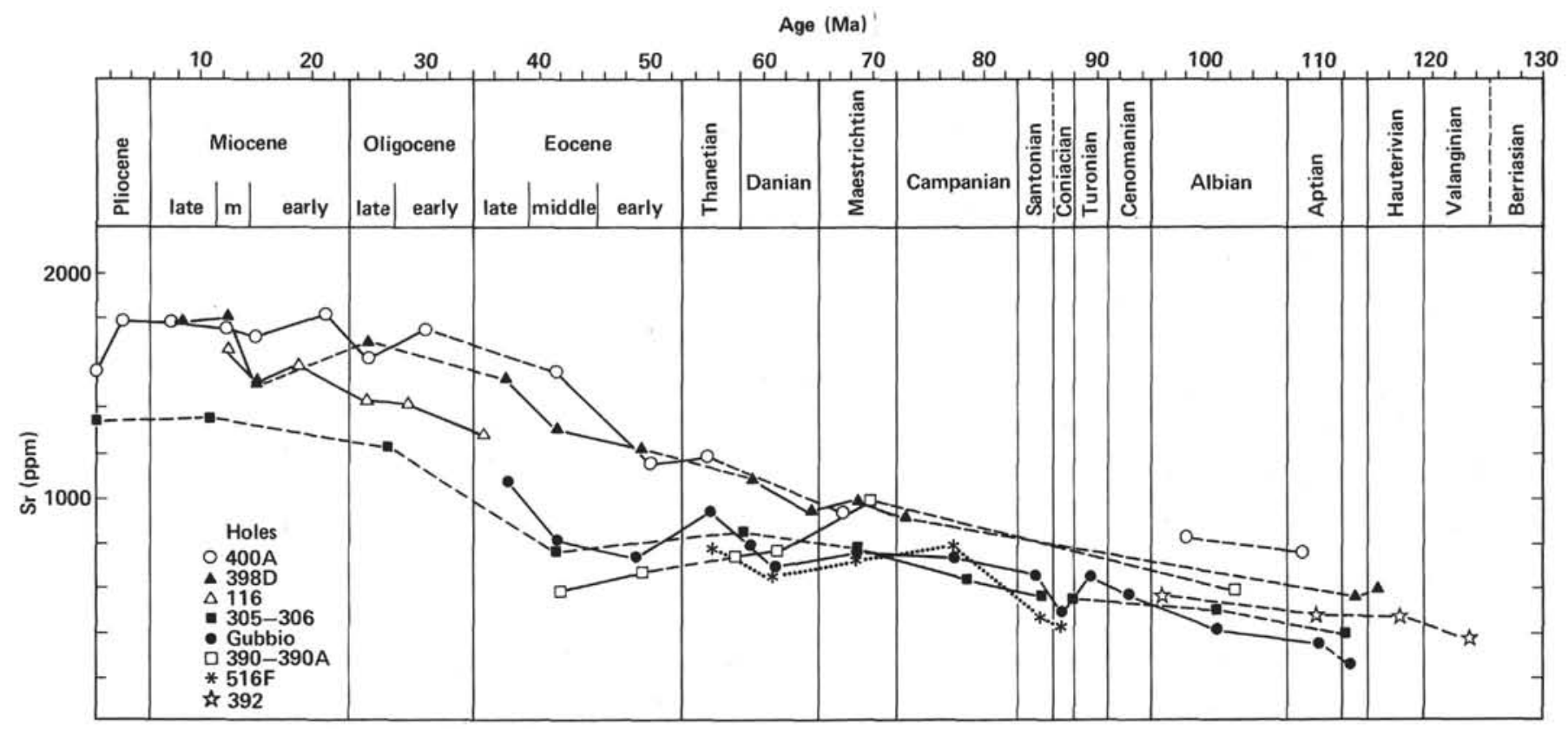

Figure 12. Carbonate strontium concentrations related to sediment ages for North Atlantic (Holes 116, 390, 390A, 392, 398D, and 400A), Tethys (Gubbio, Italy), Pacific (Sites 305-306), and South Atlantic (Hole 516F).

Because the Tethys and South Atlantic were, during the Coniacian-Thanetian, branches of the Pacific Ocean, the strontium variations in carbonates might only reflect chemical differences between Pacific and Atlantic seawater at present.

\section{OXYGEN AND CARBON STABLE ISOTOPES}

The potential use of stable isotopic ratios from calcareous nannofossils as paleoceanographic indicators has been shown by Margolis and others (1975). In the pelagic realm, nannofossils are the main producers of carbonate, and it is possible, as a first approximation, to replace isotopic ratios of calcareous nannofossils by isotopic ratios of bulk carbonates, especially when foraminifers cannot be extracted from lithified samples. Cementation and isotopic reequilibration during lithification alter the original oxygen 18 content of samples, but the carbon 13 content seems insensitive to diagenetic phenomena and shows no relationship to increasing lithification (McKenzie et al., 1978; Renard, Létolle, and Richebois, 1979). According to Weissert and others (1979): "The different species of coccoliths living in the surface waters fractionate carbon 13 equally, and subsequently selective dissolution during diagenesis will not alter the carbon 13 content of the nannofossil sediments." The carbon 13 content of bulk carbonates may, therefore, provide relatively good information on variations in carbon 13 content of the surface water. On a large scale, carbon 13 shifts seem to be related to the great transgression/regression cycles, and a striking similarity in the carbon 13 curve and the sea level variation curve has been noted (Cavelier et al., 1981).

\section{Oxygen 18}

Oxygen isotopic ratio variation does not show any particularly striking trends (Fig. 14). It should be observed,

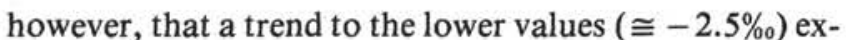
ists within the lower Maestrichtian (Cores 94, 93, and partly 92), followed by an increase towards values close to $-1.75 \%$ in the upper Maestrichtian. At the Cretaceous/Tertiary boundary (Cores 89 and 90 ) values are considerably scattered, but they tend to decrease (about -2.5 to $-3 \%$ )

Oxygen isotopic ratios become uniform again only within the upper Paleocene. This pattern is similar to that observed by Thierstein and Berger (1978) at Site 356 (Fig. 15). The significance of bulk carbonates $\delta^{18} \mathrm{O}$ in terms of paleoenvironment is speculative; however, the isotopic curves from Holes $390 \mathrm{~A}, 398 \mathrm{D}, 356$, and $516 \mathrm{~F}$ and Gubbio outcrops (Fig. 16) show striking similarities (Létolle et al., 1978; Renard, Richebois, and Létolle, 1979).

1) North Atlantic Holes 390 and 398D have, for Maestrichtian to Paleocene sediments, a $\delta^{18} \mathrm{O}$ average of about $-0.5 \%$ (Fig. 15). In spite of numerous sedimentary hiatuses, the same phenomenon can be observed at Hole 400A (Renard, Létolle, and Richebois, 1979b).

2) Values from Gubbio outcrops (Tethys) and Holes 356 and $516 \mathrm{~F}$ (South Atlantic) are between -2.0 and $-2.5 \%$.

Neither the disparity between the two groups of data nor the homogeneity of values within a given geographic area can be explained by diagenetic phenomena. A comparison of the depth in the hole and the microfacies of Maestrichtian-Danian sediments (Table 1) to isotopic data shows that there is no relationship between overloading of sediments, microfacies, and lithification on the one hand, and isotopic data on the other hand. We must consider therefore that an important part of the bulk carbonate $\delta^{18} \mathrm{O}$ (at least for the Maestrichtian-Danian sediments) is related to paleoenvironment conditions. The difference of $2 \%$ observed between sediments 


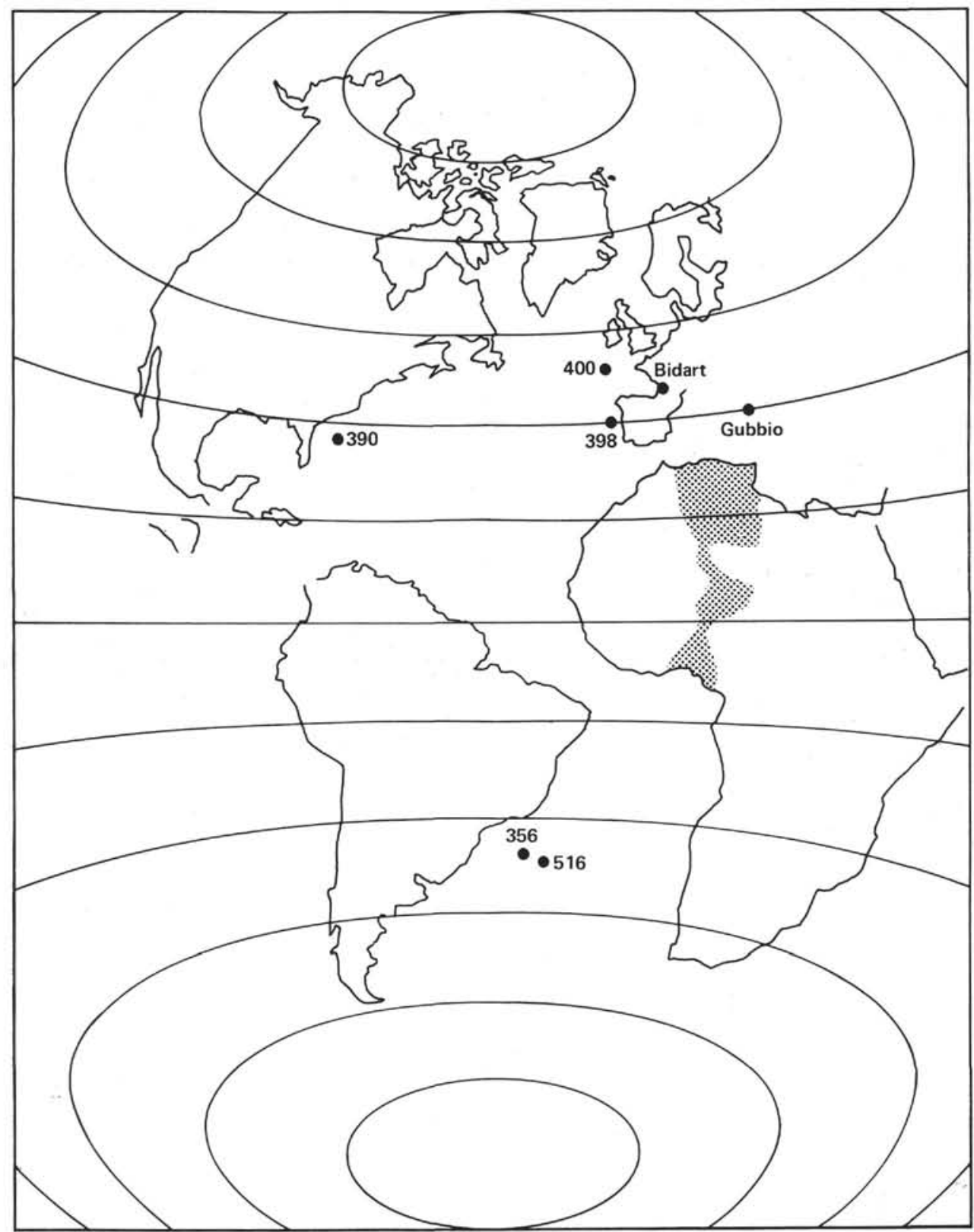

Figure 13. Paleolocation of Sites 356, 390, 398, 400, 516, Bidart, and Gubbio at 65 Ma. Paleogeographic reconstitution after Sclater et al. (1977); Tethys-South Atlantic connection after Reyment and Mörner (1977). The dotted area $=$ epicontinental sea/trans-Saharan communication.

from South Atlantic/Tethys areas and those from the North Atlantic suggests a variation of temperature close to $10^{\circ} \mathrm{C}$ between South Atlantic-Tethys surface waters (warmer) and North Atlantic surface waters (colder). The difference may not fully depend on temperatures; salinity and oxygen isotopic ratios of water may have been relatively different in the two areas. These differences show that communication between the North Atlantic and South Atlantic was still very restricted, at least until the late Paleocene. On the other hand, paleogeographic reconstruction suggests open communication between the Tethys and South Atlantic (Fig. 13). Paleontologic evidence proves that this communication arose either from a trans-Saharan connection established through the Niger Valley between an epicontinental arm of the Tethys and the Gulf of Guinea (Reyment and Mörner, 1977; Blondeau, 1977), or from the Central Atlantic (Moullade and Guerin, 1981).

\section{Carbon 13}

Carbon isotope variations are very conclusive (Fig. 14). Above stable values close to $+2.0 \%$ within the upper Campanian (Cores 100 to 96), the $\delta^{13} \mathrm{C}$ increases to $+2.5 \%$ within the lower Maestrichtian (Cores 95 to 94 ), then level off in the main part of Maestrichtian (Cores 94 to 90). Values begin to decrease at the uppermost Maestrichtian and reach a minimum of $+1 \%$ in the lowest Paleocene (Core 89). Within the Paleocene and 


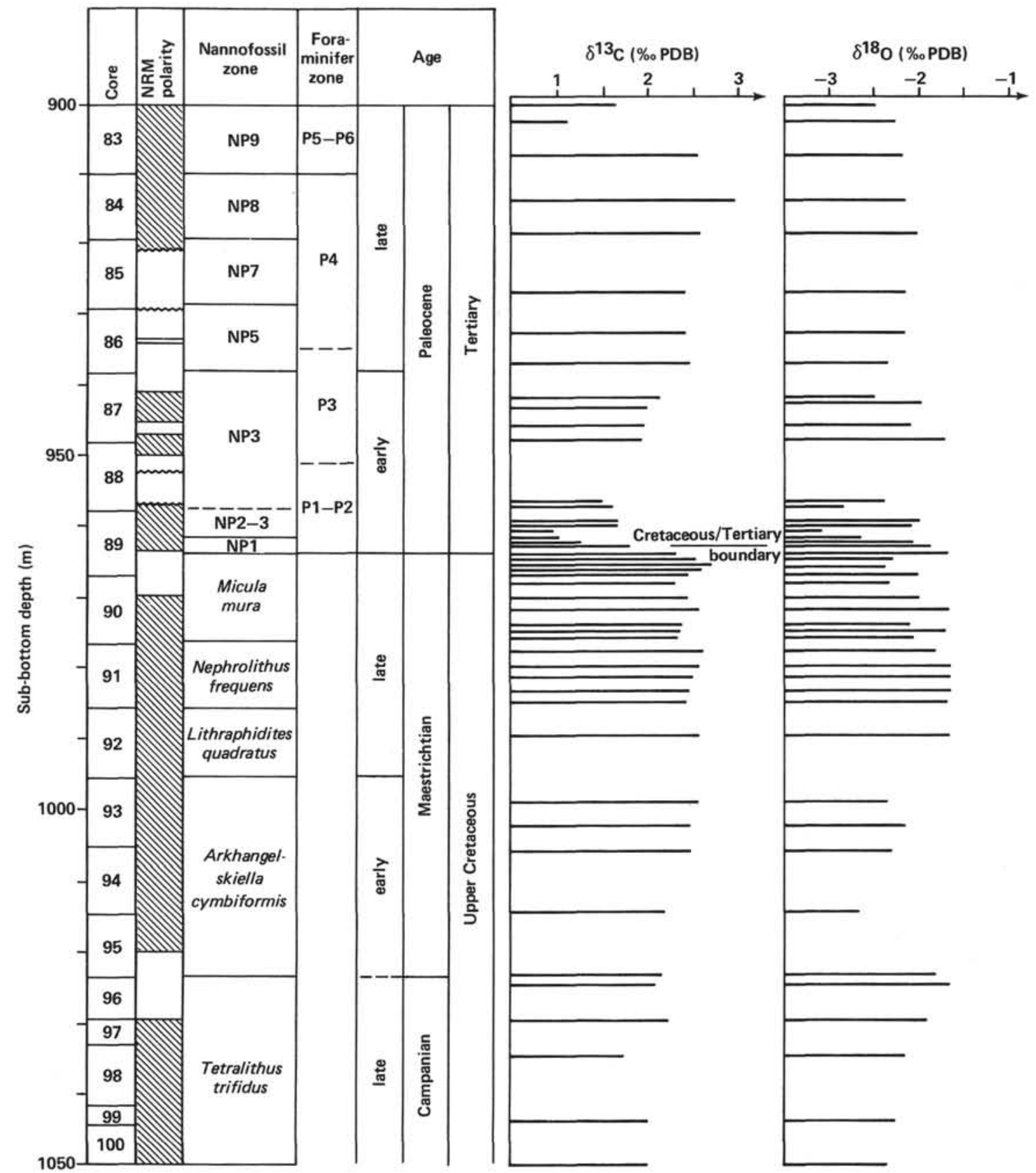

Figure 14. Oxygen and carbon isotope variations during the Cretaceous/Tertiary transition at Hole 516F. NRM = natural remanent magnetization.

particularly within the Thanetian (Cores 88 to 84 ), values rise again to $+3 \%$. A new negative excursion occurs at the top of Paleocene. These two negative shifts located at Cretaceous/Tertiary and Paleocene/Eocene boundaries are present in many DSDP sites and in continental outcrops (e.g., Kroopnick et al., 1977; Scholle and Arthur, 1980; Létolle and Renard, 1980). Comparison between carbon 13 curves of various sites (Figs. 17, 18) leads to the following conclusions:

1) The $\delta^{13} \mathrm{C}$ shift at the Cretaceous/Tertiary boundary is more gradual than apparent. The abrupt aspect of the shift is, more often than not, due either to an incomplete sampling or to a pronounced sedimentary hiatus at this boundary. When there is continuous sedimentation (i.e., when G. eugubina Zone is present), the decline of isotopic ratio is gradual. This gradual transition may be in part caused, however, by reworking of Cretaceous thin sediment into the lowermost Paleocene levels; the sediment is a product of mixing of high isotopic ratio carbonate (Cretaceous) and low isotopic ratio carbonate (Paleocene). The lowest values are for samples located in Zones P1C/P1D. Moreover, in detail, two $\delta^{13} \mathrm{C}$ isotopic minima may exist, the first one at the top of Zone P1A and the second one at the lower part of Zone P1D. The offset between these minima can be seen on the curves for Holes 390 and $516 \mathrm{~F}$ and Gubbio.

2) The parallelism of isotopic curves achieved at different sites is noteworthy and supports our assertion 


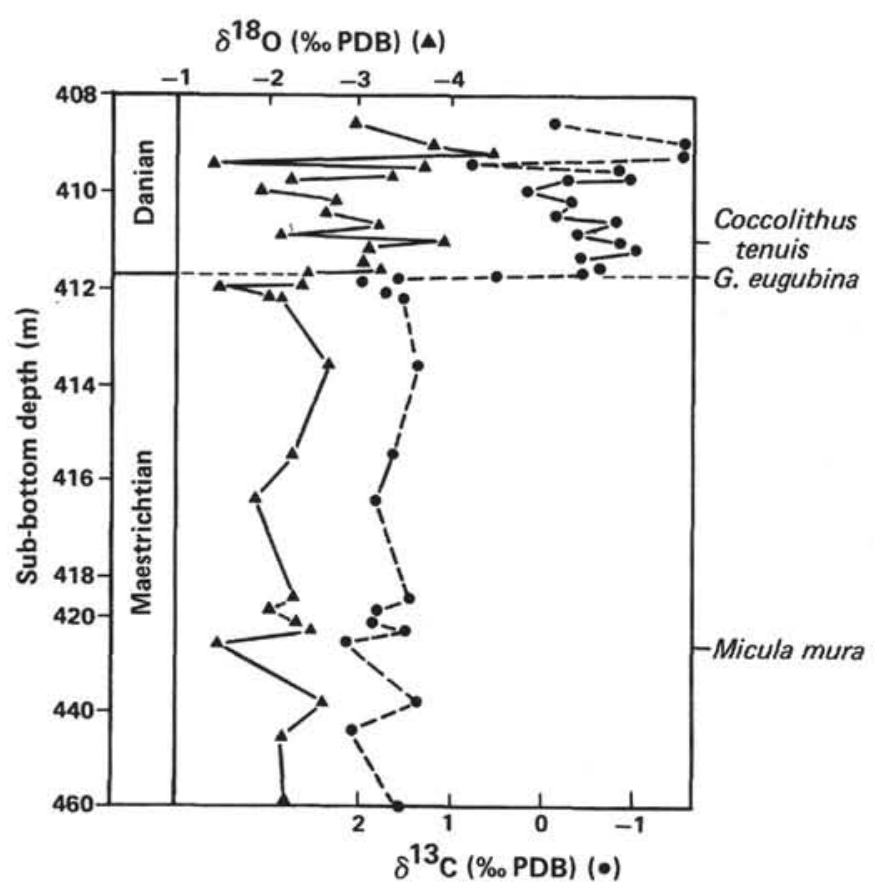

Figure 15. Stable isotope curve of the fine fraction carbonate for DSDP Site 356, South Atlantic (modified after Thierstein and Berger, 1978). Triangles indicate $\delta^{18} \mathrm{O}$ statistics; circles are $\delta^{13} \mathrm{C}$ statistics.

Table 1. Comparison of lithofacies and depth of the Cretaceous/Tertiary boundary.

\begin{tabular}{lll}
\hline Hole & $\begin{array}{c}\text { Depth of Cretaceous/ } \\
\text { Tertiary boundary }(\mathrm{m})\end{array}$ & \multicolumn{1}{c}{ Facies } \\
\hline 390A & 150 & Ooze \\
398D & 800 & Chalk \\
400A & 650 & Marly nannochalk \\
Gubbio & On-shore outcrops & Siliceous limestones \\
$516 \mathrm{~F}$ & 960 & Marly nannochalk \\
356 & 410 & Marly nannochalk \\
\hline
\end{tabular}

that $\delta^{13} \mathrm{C}$ bulk carbonates are a potential stratigraphic tool.

3) Isotopic data of South Atlantic and Tethys sites as well as those of North Atlantic sites are very similar: $+2.5 \%$ in the Maestrichtian, $+1.5 \%$ in the upper Danian, $+3.0 \%$ in the Thanetian, and $+1.0 \%$ at the Paleocene/Eocene boundary. This constancy of $\delta^{13} \mathrm{C}$ values between very distant localities suggests that, unlike the $\delta^{18} \mathrm{O}$ fluctuations, the cause of carbon isotopic ratio variations is a worldwide oceanic phenomenon relatively independent of local conditions. ${ }^{2}$

Only the amplitude of the Cretaceous/Tertiary boundary shift seems variable: $1.25 \%$, Gubbio (Italy); $1.50 \%$, Hole $516 \mathrm{~F} ; 2.50 \%$, Holes 398 and 356 ; and $3.50 \%$, Bidart (Biscaye, France).

\footnotetext{
${ }^{2}$ In some instances, as at Site 356 and at the Bidart outcrops (Figs. 14 and 18 ), the $\delta^{13} \mathrm{C}$ negative shift of Cretaceous/Tertiary boundary is linked to a $\delta^{18} \mathrm{O}$ negative excursion. At the present time, however, there are not enough available data to know if this is a local or a general phenomenon, or if it is due to early diagenesis or variations in environmental conditions. At Bidart (France), Delacotte (1982) shows that after this $\delta^{18} \mathrm{O}$ sharp negative shift, there is a progressive positive excursion caused by variations in local environmental conditions; the main oceanic influences came from the Tethys (low $\delta^{18} \mathrm{O}$ ) during the Maestrichtian and from the North Atlantic (high $\delta^{18} \mathrm{O}$ ) during and after the Paleocene.
}

If, as we think, negative excursions of $\delta^{13} \mathrm{C}$ curve are, more or less, related to global sea level regressions, it is not surprising that the shallower sites show the greatest amplitude of variations.

An attempt at an explanation of the phenomenon can be taken from Kroopnick $(1974,1977)$, Weissert and others (1979), Létolle and Renard (1980): the organic material produced in the surface water is depleted in carbon 13, and the decomposition of this material on the bottom of the ocean releases $\mathrm{CO}_{2}$ to the deep water. The surface waters are, therefore, relatively enriched in carbon 13 , whereas deep waters are relatively depleted. Upwelling and mixing return these carbon 13-depleted waters to the surface and prevent an extensive enrichment of carbon 13 in the euphotic zone. Times of high sea level (transgression) appear to correspond to anoxic conditions in the ocean with a very stable salinity stratification and sluggish circulation (Fisher and Arthur, 1977; Scholle and Arthur, 1980). During these periods, the surface of the euphotic zone is very large and, because the oceanic circulation is greatly diminished, there is less mixing of carbon 13-depleted deep waters with surface waters. Nannofossils living during these periods will be relatively enriched in carbon 13 . During regressive time (low sea level), the surface of the euphotic zone is reduced, and the restarting of oceanic circulation permits the mixing of carbon 13-depleted deep waters with carbon 13-enriched surface waters. Nannofossils living during these periods will be relatively depleted in carbon 13 .

\section{CONCLUSIONS}

Geochemical studies of Coniacian-Santonian sediments from Hole $516 \mathrm{~F}$ indicate:

1) If Site $356 \delta^{13} \mathrm{C}$ results are confirmed in their broad outline, the Cretaceous/Tertiary shift is not as sharp as anticipated. The most negative values are located in P1C/P1D planktonic foraminifer zones and not in the G. eugubina Zone. Interpretations, extraterrestrial or not, of the Cretaceous/Tertiary crisis must take into consideration the relatively gradual aspect of $\delta^{13} \mathrm{C}$ variations.

2) At least for the studied part of geologic time scale, the $\delta^{18} \mathrm{O}$ record in bulk carbonates is not completely destroyed by diagenesis.

3) Variations in strontium and carbon 13 content in carbonates should be considered as potential tools for stratigraphic correlations.

4) For pelagic sediments, strontium and sodium contents of carbonates fluctuate in a parallel fashion, and strontium and magnesium contents vary inversely.

5) Chemical data suggest a very restricted communication between the North and South Atlantic during the Coniacian-Thanetian. On the contrary, Tethys, South Atlantic, and Pacific communication seems to have been very open.

\section{ACKNOWLEDGMENTS}

We are very grateful to K. Perch-Nielsen, I. Premoli Silva, and C. Pujol for their help in biostratigraphic zonations; to Dr. C. Vergnaud Grazzini and J. Gieskes for reviewing the text and to Dr. B. Coulbourn for many corrections and very helpful criticisms. Many thanks are also owed to E. Truptil and A. M. Rossetto for laboratory assis- 


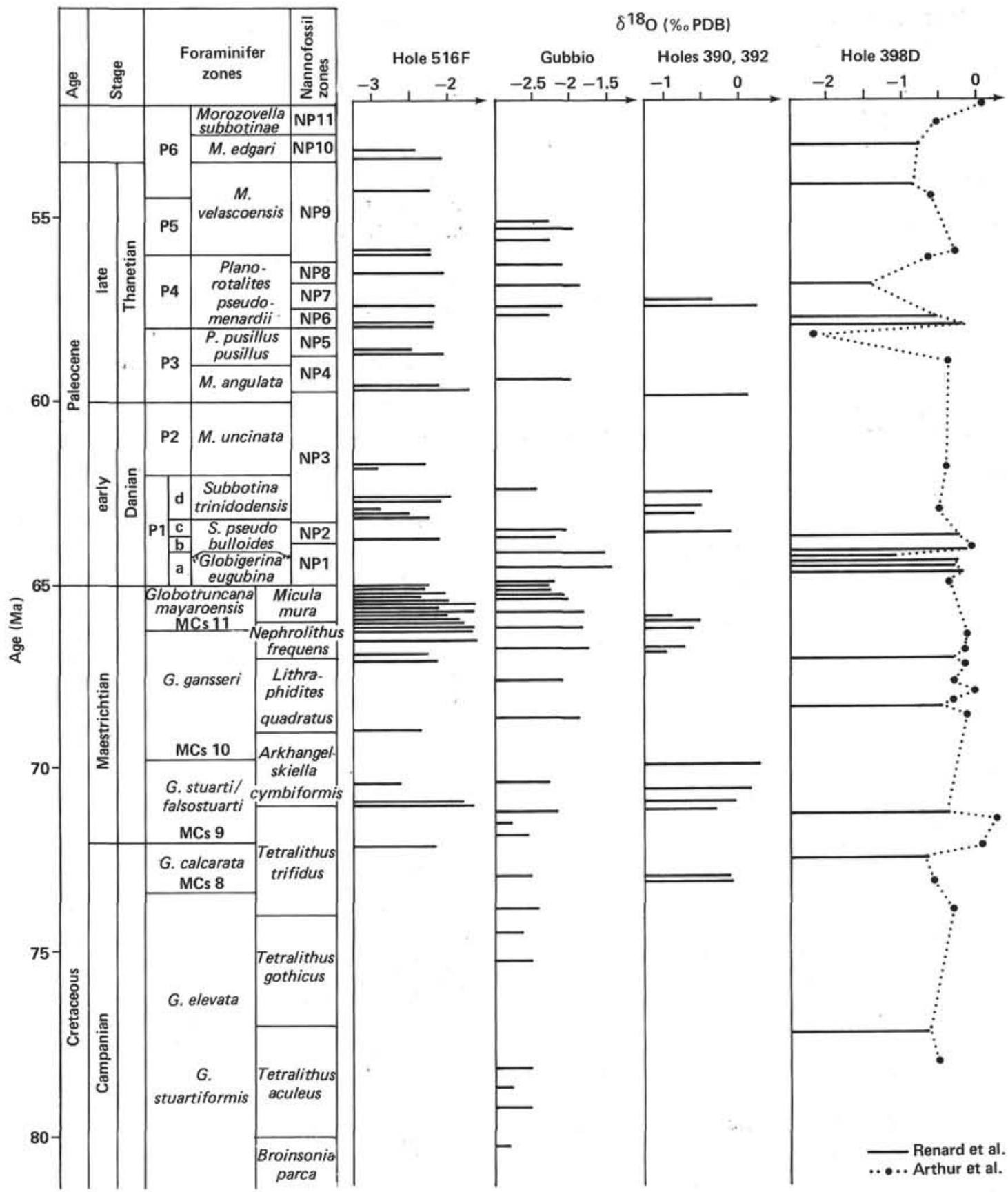

Figure 16. Oxygen isotope (bulk carbonates) curve for North Atlantic (Holes 390, 392, and 398D), Tethys (Gubbio, Ita-

ly), and South Atlantic (Hole 516F).

tance, M. Perzold for preparation of the figures, L. de Saboulin for correction of English text, and M. Arsalane and A. Dindeleux for typing various drafts of the manuscript. Funds for this research were provided by Centre National de la Recherche Scientifique through Action Thematique Programmée IPOD and Géologie et Géophysique des Océans.

\section{REFERENCES}

Baker, P. A., Gieskes, J. M., Elderfield, H., 1982. Diagenesis of carbonates in deep-sea sediments. Evidence from $\mathrm{Sr} / \mathrm{Ca}$ ratios and interstitial dissolved $\mathrm{Sr}^{2+}$ data. J. Sediment. Petrol. 52(1):71-82.

Blechschmidt, G., 1979. Biostratigraphy of calcareous nannofossils: Leg 47B, Deep Sea Drilling Project. In Sibuet, J.-C., Ryan, W. B. F., et al., Init. Repts. DSDP, 47, Pt. 2: Washington (U.S. Govt. Printing Office), 327-360.
Blondeau, A., 1977. Mise en évidence des relations entre l'Afrique et l'Amérique du Sud à l'aide des Nummulithes. Deuxième Colloque Latino-Américain, pp. 1451-1460.

Cavelier, C., Chateauneuf, J. J., Pomerol, C., Rabussier, D., Renard, M., and Vergnaud Grazzini, C., 1981. Geologic events at the Eocene-Oligocene boundary. Palaeogeogr. Palaeoclimatol. Palaeoecol., 36:223-248.

Delacotte, O., 1982. Étude magnétostratigraphique et géochimique de la limite cretace-tertiare de la coupe de Bidart (Pyrénées-Atlantiques). Thèse de $3^{\mathrm{ème}}$ cycle. Univ. Pierre-et-Marie-Curie Mémoire No. 8218.

Fischer, A. G., and Arthur, M. A., 1977. Secular variations in the pelagic realm. Soc, Econ. Paleontol. Mineral., Spec. Publ, 25:19-50.

Gradstein, F. M., Bukry, D., Habib, D., Renz, O., Roth, P. H., Schmidt, R. R., Weaver, F. M., and Wind, F. H., 1978. Bio- 
stratigraphic summary of DSDP Leg 44: Western North Atlantic Ocean. In Benson, W. E., Sheridan, R. E., et al., Init. Repts. DSDP, 44: Washington (U.S. Govt. Printing Office), 657-662.

Hardenbol, J., and Berggren, W. A., 1978. A new Paleogene numerical time scale. In Cohee, G. V., Glaessner, M. F., and Hedberg, H. D. (Eds.), Contributions to the Geologic Time Scale: Tulsa (Am. Assoc. Pet. Geol.), 6:213-235.

Iaccarino, S., and Premoli Silva, I., 1979. Paleogene planktonic foraminiferal biostratigraphy of DSDP Hole 398D. In Sibuet, J.-C., Ryan, W. B. F., et al., Init. Repts. DSDP, 47, Pt. 2: Washington (U.S. Govt. Printing Office), 237-254.

Kinsman, D. J. J., 1969. Interpretation of $\mathrm{Sr}^{2+}$ concentrations in carbonate minerals and rocks. J. Sediment. Petrol. 39:486-508.

Kroopnick, P., 1974. The dissolved $\mathrm{O}_{2}-\mathrm{CO}_{2}-\delta^{13} \mathrm{C}$ system in the eastern equatorial Pacific. Deep-Sea Res. 21:211-277.

Kroopnick, P., Margolis, S. V., and Wong, C. S., 1977. $\delta^{13} \mathrm{C}$ variations in marine carbonate sediments as indicators of the $\mathrm{CO}_{2}$ balance between the atmosphere and oceans. In Andersen, N. R., and Malahoff, A. (Eds.), The Fate of Fossil Fuel $\mathrm{CO}_{2}$ in the Ocean: New York (Plenum Press), pp. 295-321.

Létolle, R., Fontes, J. C., and Tivolier, J., 1965. A tentative interpretation of oxygen isotope analysis of Tertiary mollusques of the Paris Basin. Comm. Coll. Geol. Nucleaire., pp. 1-11.

Létolle, R., Renard, M., Bourbon, M., and Filly, A., 1978. $\mathrm{O}^{18}$ and $\mathrm{C}^{13}$ isotopes in Leg 44 carbonates: a comparison with the Alpine series. In Benson, W. E., Sheridan, R. E., et al., Init. Repts. DSDP, 44: Washington (U.S. Govt. Printing Office), 567-574.

Lorens, R. B., Williams, D. F., and Bender, M. C., 1977. Early monstructural chemical diagenesis of foraminiferal calcite. J. Sediment. Petrol. 47(4):1602-1609.

McKenzie, J., Bernoulli, D., and Garrisson, R. E., 1978. Lithification of pelagic-hemipelagic sediments at DSDP Site 372: oxygen isotope alteration with diagenesis. In Hsü, K. J., Montadert, L., et al., Init. Repts. DSDP, 42, Pt. 1: Washington (U.S. Govt. Printing Office), 473-478.

Margolis, S. V., et al, 1975. Oxygen and carbon isotopes from calcareous nannofossils as paleo-oceanographic indicators. Science 189: 555-557.

Matter, A., Douglas, R. G., and Perch-Nielsen, K., 1975. Fossil preservation, geochemistry and diagenesis of pelagic carbonates from Shatsky Rise, Northwest Pacific. In Larson, R. L., Moberly, R., et al., Init. Repts. DSDP, 32: Washington (U.S. Govt. Printing Office), 891-921.

Moulade, M., and Guerin, S., 1981. Le problème des relations de l'Atlantique Sud et de l'Atlantique central au crétacé moyen: nouvelles données microfaunistiques d'après les forages DSDP. Bull. Géol. Soc. Fr. 7(24):511-517.

Müller, C., 1979. Calcareous nannofossils from the North Atlantic (Leg 48). In Montadert, L., Roberts, D. G., et al., Init. Repts. DSDP, 48: Washington (U.S. Govt. Printing Office), 589-640.

Odin, G. S., 1978. Results of dating Cretaceous Paleocene sediments Europe. AAPG Stud. Geol. 6:127-141.

Odin, G. S., 1982. Geological time scale. In Odin, G. S. (Ed.), Numerical Dating in Stratigraphy: New York (J. Wiley Publishers), pp. 3-16.

Odin, G. S., Renard, M., and Vergnaud Grazzini, C., 1982. Geochemical events as a mean of correlation. In Odin, G. S. (Ed.), Numerical Dating in Stratigraphy: New York (J. Wiley Publishers), pp. 37-71.

Perch-Nielsen, K., 1977. Albian to Pleistocene calcareous nannofossils from the western South Atlantic DSDP Leg 39. In Supko, P. R., Perch-Nielsen, K., et al., Init. Repts. DSDP, 39: Washington (U.S. Govt. Printing Office, 699-747.

1979. Calcareous nannofossils at the Cretaceous/Tertiary boundary near Biarritz, France, Cretaceous/Tertiary Boundary Events Symp., pp. 151-155.

Premoli Silva, I., and Boersma, A., 1977. Cretaceous planktonic foraminifers-DSDP Leg 39 (South Atlantic). In Supko, P. R., PerchNielsen, K, et al., Init. Repts. DSDP, 39: Washington (U.S. Govt. Printing Office), 615-638.
Premoli Silva, I., and Paggi, L., 1976. Cretaceous through Paleocene biostratigraphy of the pelagic sequence at Gubbio Italy. Mem. Soc. Geol. It., 15:21-32.

Renard, M., 1979. Aspect géochimique de la diagenese des carbonates. Teneur en $\mathrm{Sr}$ et $\mathrm{Mg}$ des carbonates: essai d'intérpretation de l'inversion de la correlation $\mathrm{Sr} / \mathrm{Mg}$ observée dans les carbonates du domaine pelagique par rapport à ceux du domaine neritique. Bull. Bur. Rech. Geol. Min., Sec. 4: (Fr.) 2:133-152.

Renard, M., and Blanc, P., 1971. Mise au point d'un protocole expérimental pour le dosagé d'éléments en traces $(\mathrm{V}, \mathrm{Cr}, \mathrm{Mn}, \mathrm{Ni}, \mathrm{Sr}$, Mo) par absorption atomique $C$. Hebd. Seances Acad. Sci. Ser. D 272:2285-2288.

1972. Influence des conditions de mise en solution (Choix de l'acide température et durée d'attaque) dans le dosage des élémente en traces des roches carbonatées. C. R. Hebd. Seances Acad. Sci. Ser. D 274:632-635.

Renard, M., and Létolle, R., 1980. Evolution des teneurs en ${ }^{13} \mathrm{C}$ des carbonates pélagiques aux limites cretacé-tertiaire et Paleocene Eocene. C. R. Hebd. Seances Acad. Sci. Ser. D 290:827-830.

Renard, M., Létolle, R., Bourbon, M., and Richebois, G., 1978. Some trace elements in the carbonate samples recovered from Holes 390 , $390 \mathrm{~A}, 391 \mathrm{C}$, and 392A of DSDP Leg 44. In Benson, W. E., Sheridan, R. E., et al., Init. Repts. DSDP, 44: Washington (U.S. Govt. Printing Office), 557-566.

Renard, M., Létolle, R., and Richebois, G., 1979. Some trace elements and their relation to oxygen and carbon isotopes in the carbonate samples recovered from Hole 400A of DSDP Leg 48. In Montadert, L., Roberts, D. G., et al., Init. Repts. DSDP, 48: Washington (U.S. Govt. Printing Office), 727-739.

Renard, M., Richebois G., and Létolle, R., 1979. Strontium, manganese, and iron contents, and oxygen isotopes in the carbonate fractions recovered from Hole 398C, Leg 47B. In Sibuet, J.-C., Ryan, W. B. F., et al., Init. Repts. DSDP, 47, Pt. 2: Washington (U.S. Govt. Printing Office), 497-506.

Reyment, R. A., and Mörner, N. A., 1977. Cretaceous transgressions and regressions exemplified by the South Atlantic, mid-Cretaceous events, Hokkaido symposium. Paleontol. Soc. Jpn. Sp. Papers 21:247-261.

Scholle, P. A., and Arthur, M. A., 1980. Carbon isotope fluctuations in Cretaceous pelagic limestones. AAPG Bull. 64(1):67-87.

Sclater, J. G., Hellingen, S., and Tapscott, C., 1977. The paleobathymetry of the Atlantic Ocean from the Jurassic to the present. $J$. Geol. 85(5):509-552.

Sigal, J., 1977. Essai de zonation du cretace mediterranéen à l'aide des foraminiferes planctoniques. Géol. Méditerr. 4(2):99-108.

Thierstein, M. R., and Berger, W. H., 1978. Injection events in ocean history. Nature 279(5687):461-466.

Weissert, H., McKenzie, J., and Hockuli, P., 1979. Cyclic anoxic events in the Early Cretaceous Tethys Ocean. Geology 7:147-151.

Date of Initial Receipt: October 14, 1981

\section{APPENDIX A \\ Biostratigraphic Ages}

Biostratigraphic ages were assigned to samples using various publications:

Gubbio section: Premoli Silva et al. (1976)

Sites 305-306, 356: Perch-Nielsen (1977)

Hole 398D: Iccarino and Premoli Silva (1979), Blechschmidt (1979), Sigal (1979)

Hole 400A: Müller (1979)

Hole 516F: Pujol (this volume)

Bidart section Perch-Nielsen (1979 and personal communication, 1982). Foraminiferal and nannoplankton zone durations and absolute ages of each sample are based on Hardenbol and Berggren (1978) and Odin (1978 and in press) time scales and publications of Premoli Silva and Boersma (1977), Sigal (1977), and Perch-Nielsen (1977). 
APPENDIX B

Data Summary of Carbonate Fraction Analysis, Hole 516F

\begin{tabular}{|c|c|c|c|c|c|c|c|}
\hline $\begin{array}{c}\text { Core-section } \\
\text { (interval in cm) }\end{array}$ & $\begin{array}{c}\mathrm{CaCO}_{3} \\
(\%)\end{array}$ & $\mathrm{Mg}$ & $\mathrm{Na}$ & K & Mn & $\mathrm{Sr}$ & $\mathrm{Ni}$ \\
\hline $38-1,98-100$ & 92.07 & 1,292 & 424 & 163 & 215 & 1185 & -7 \\
\hline $39-1,42-44$ & 87.34 & 1319 & 455 & 224 & 214 & 1266 & 7 \\
\hline $39-2,37-39$ & 86.31 & 1073 & 491 & 262 & 210 & 1347 & 5 \\
\hline $40-1,95-97$ & 89.03 & 1274 & 429 & 208 & 188 & 1305 & 3 \\
\hline $47-1,18-19$ & 89.67 & 1765 & 499 & 208 & 202 & 1160 & 5 \\
\hline $81-2,101-103$ & 94.01 & 1211 & 444 & 101 & 430 & 591 & 2 \\
\hline 83-1,? & 91.30 & 1687 & 523 & 190 & 370 & 652 & 5 \\
\hline $83-3,10-12$ & 87.45 & 1252 & 381 & 233 & 655 & 774 & 8 \\
\hline $83-5,24-26$ & 89.18 & 882 & 556 & 221 & 495 & 977 & 3 \\
\hline $84-3,80-82$ & 84.80 & 2294 & 623 & 225 & 688 & 990 & 3 \\
\hline $85-1,51-53$ & 87.40 & 770 & 569 & 180 & 790 & 1033 & 1 \\
\hline $85-5,100-102$ & 88.75 & 2473 & 389 & 122 & 547 & 1015 & 4 \\
\hline $86-3,140-141$ & 87.43 & 3195 & 593 & 209 & 567 & 1030 & 7 \\
\hline $86-6,26-28$ & 88.61 & 2695 & 396 & 112 & 545 & 1029 & 3 \\
\hline $87-3,105-107$ & 88.78 & 4316 & 383 & 109 & 636 & 838 & 4 \\
\hline $87-4,3-5$ & 89.66 & 3925 & 523 & 114 & 734 & 739 & 5 \\
\hline $87-5,96-98$ & 86.44 & 2698 & 441 & 140 & 651 & 723 & 3 \\
\hline $89-1,55-57$ & 78.80 & 1748 & 419 & 206 & 699 & 653 & 2 \\
\hline $89-3,68-70$ & 15.23 & 12,425 & 1200 & 4152 & 665 & 1299 & 14 \\
\hline $89-4,52-55$ & 55.37 & 7633 & 626 & 718 & 1133 & 693 & 8 \\
\hline $89-6,54-56$ & 82.07 & 2506 & 330 & 198 & 850 & 804 & 3 \\
\hline $90-1,66-68$ & 79.04 & 1644 & 310 & 226 & 607 & 948 & 2 \\
\hline $90-2,52-56$ & 73.64 & 2354 & 322 & 303 & 679 & 945 & 4 \\
\hline $90-3,103-105$ & 60.53 & 6229 & 431 & 559 & 687 & 730 & 8 \\
\hline $90-4,99-100$ & 81.61 & 2820 & 365 & 162 & 558 & 731 & 3 \\
\hline $90-5,42-44$ & 81.53 & 2477 & 401 & 172 & 696 & 724 & 3 \\
\hline $90-6,14-16$ & 82.53 & 2790 & 282 & 161 & 746 & 751 & 2 \\
\hline $91-1,49-50$ & 76.84 & 2551 & 311 & 209 & 643 & 728 & 3 \\
\hline $91-2,145-147$ & 81.49 & 2717 & 376 & 195 & 630 & 796 & 3 \\
\hline $91-3,126-128$ & 78.48 & 3733 & 356 & 238 & 582 & 737 & 3 \\
\hline $91-4,51-53$ & 81.42 & 3942 & 397 & 194 & 510 & 768 & 5 \\
\hline $91-5,106-108$ & 54.01 & 7094 & 375 & 682 & 743 & 776 & 9 \\
\hline $91-6,1-3$ & 72.47 & 6300 & 504 & 285 & 570 & 787 & 8 \\
\hline $92-3,56-57$ & 56.49 & 6233 & 449 & 697 & 435 & 862 & 8 \\
\hline $93-3,127-129$ & 77.07 & 1305 & 629 & 267 & 810 & 747 & 1 \\
\hline $93-5,12-14$ & 42.20 & 2051 & 549 & 1197 & 761 & 884 & 7 \\
\hline $94-2,126-128$ & 68.72 & 7754 & 356 & 472 & 1045 & 609 & 5 \\
\hline $95-1,55-57$ & 72.98 & 6208 & 376 & 291 & 1179 & 663 & 5 \\
\hline $96-1,66-68$ & 60.45 & 9085 & 450 & 666 & 1162 & 722 & 7 \\
\hline $96-2,12-13$ & 73.55 & 8783 & 541 & 317 & 1317 & 779 & 7 \\
\hline $97-2,64-65$ & 52.89 & 3128 & 473 & 938 & 1265 & 862 & 12 \\
\hline $98-2,82-83$ & 58.47 & 3419 & 404 & 742 & 1081 & 729 & 19 \\
\hline $100-1,27-29$ & 54.15 & 6451 & 494 & 828 & 1162 & 809 & 5 \\
\hline $101-1,114-116$ & 67.80 & 6404 & 433 & 575 & 1293 & 784 & 5 \\
\hline $102-1,111-113$ & 73.98 & 6718 & 351 & 303 & 1239 & 786 & 4 \\
\hline $102-2,96-98$ & 34.19 & 13,162 & 790 & 1645 & 897 & 942 & 26 \\
\hline $102-3,68-70$ & 49.21 & 8758 & 784 & 915 & 1258 & 940 & 13 \\
\hline $103-2,98-100$ & 55.29 & 7235 & 422 & 642 & 876 & 916 & 10 \\
\hline $104-1,38-40$ & 72.42 & 13,686 & 469 & 236 & 1086 & 803 & 16 \\
\hline $104-2,122-125$ & 68.23 & 5366 & 339 & 292 & 835 & 933 & 7 \\
\hline $104-6,48-50$ & 61.56 & 7433 & 361 & 339 & 867 & 855 & 10 \\
\hline $105-1,42-44$ & 68.54 & 4426 & 261 & 225 & 855 & 820 & 6 \\
\hline $105-5,72-74$ & 57.17 & 1010 & 240 & 322 & 978 & 861 & 4 \\
\hline $106-2,65-67$ & 71.65 & 766 & 242 & 168 & 855 & 818 & 2 \\
\hline $106-6,68-70$ & 67.28 & 1372 & 286 & 260 & 883 & 626 & 4 \\
\hline $107-7,40-43$ & 62.46 & 1197 & 270 & 290 & 804 & 736 & 4 \\
\hline $108-2,112-114$ & 62.24 & 6323 & 312 & 395 & 1013 & 653 & 12 \\
\hline $108-4,44-45$ & 63.08 & 2522 & 295 & 297 & 677 & 719 & 6 \\
\hline $109-3,75-77$ & 75.22 & 3679 & 251 & 235 & 636 & 684 & 7 \\
\hline $109-4,41-43$ & 71.63 & 2340 & 243 & 281 & 574 & 739 & 6 \\
\hline $110-1,50-52$ & 60.15 & 3415 & 258 & 419 & 491 & 738 & 8 \\
\hline $110-3,144-146$ & 65.90 & 7054 & 312 & 315 & 526 & 654 & 11 \\
\hline $112-1,64-66$ & 73.66 & 8000 & 330 & 247 & 725 & 515 & 9 \\
\hline $113-3,52-54$ & 53.60 & 4779 & 456 & 428 & 672 & 567 & 14 \\
\hline $113-6,40-44$ & 43.04 & 4618 & 448 & 528 & 725 & 508 & 16 \\
\hline $114-1,109-111$ & 82.62 & 1393 & 198 & 97 & 922 & 310 & 4 \\
\hline $114-3,60-62$ & 62.98 & 6845 & 425 & 251 & 838 & 467 & 17 \\
\hline $114-6,116-115$ & 69.78 & 2908 & 262 & 172 & 773 & 383 & 7 \\
\hline $115-1,27-29$ & 49.61 & 5449 & 526 & 459 & 759 & 507 & 18 \\
\hline $115-4,27-29$ & 69.40 & 2137 & 324 & 190 & 881 & 319 & 7 \\
\hline $116-1,125-127$ & 76.65 & 3187 & 315 & 127 & 770 & 314 & 9 \\
\hline $116-3,31-33$ & 40.83 & 4602 & 526 & 582 & 614 & 600 & 17 \\
\hline $116-6,60-62$ & 77.32 & 3219 & 274 & 161 & 758 & 371 & 8 \\
\hline 117-1, ? & 79.04 & 1840 & 279 & 164 & 920 & 332 & 4 \\
\hline $117-4,22-24$ & 67.45 & 2626 & 359 & 260 & 685 & 466 & 7 \\
\hline $117-6,16-18$ & 63.01 & 3199 & 345 & 344 & 640 & 445 & 10 \\
\hline $118-1, ?$ & 83.28 & 2893 & 230 & 120 & 769 & 260 & 5 \\
\hline $118-3,14-16$ & 85.38 & 1335 & 187 & 117 & 694 & 260 & 2 \\
\hline $119-1,119-12]$ & 79.17 & 1334 & 254 & 165 & 800 & 353 & 3 \\
\hline $119-3,85-87$ & 70.94 & 3405 & 321 & 169 & 617 & 355 & 8 \\
\hline $120-1,36-38$ & 65.29 & 4084 & 371 & 126 & 773 & 384 & 9 \\
\hline $120-2,0-32$ & 54.72 & 7250 & 483 & 100 & 961 & 368 & 10 \\
\hline $121-1,61-63$ & 68.47 & 2645 & 305 & 73 & 1126 & 270 & 4 \\
\hline $122-1,35-37$ & 54.57 & 24,669 & 736 & 78 & 1194 & 288 & 21 \\
\hline $122-2,120-122$ & 56.36 & 3286 & 378 & 76 & 1935 & 317 & 4 \\
\hline $123-1,53-55$ & 56.71 & 1426 & 311 & 67 & 4538 & 393 & 6 \\
\hline $124-1,20-22$ & 76.23 & 4516 & 401 & 216 & 4171 & 162 & 2 \\
\hline $124-2,25-27$ & 22.52 & 9242 & 663 & 2864 & 7302 & 482 & 10 \\
\hline $125-1,24-26$ & 39.96 & 3893 & 305 & 1246 & 3644 & 267 & 1 \\
\hline $124-1,20-22$ & 91.41 & 3696 & 3219 & 677 & 4172 & 381 & 46 \\
\hline
\end{tabular}




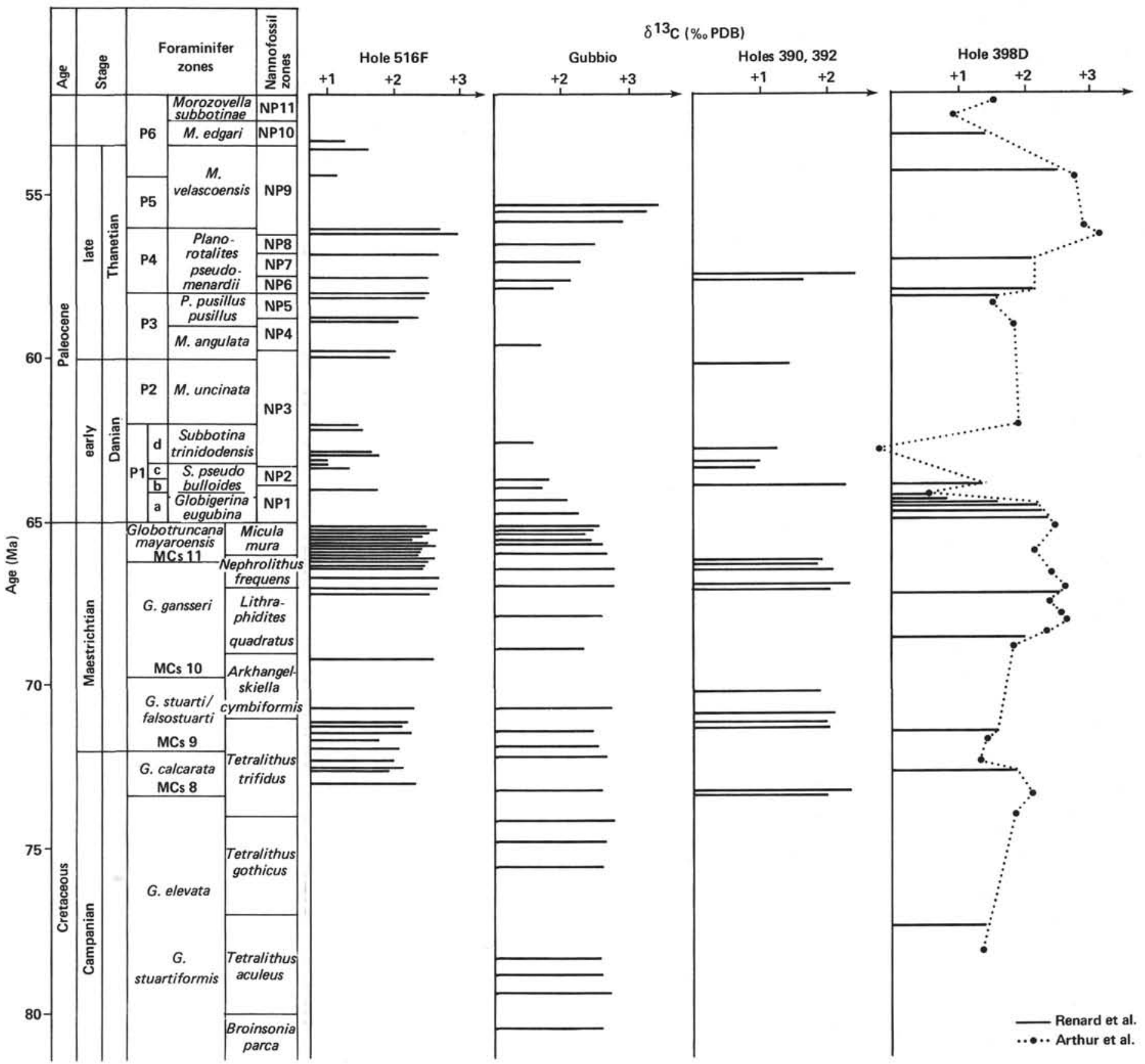

Figure 17. Carbon isotope curve for North Atlantic (Holes 390, 392, and 398D), Tethys (Gubbio, Italy), and South Atlantic (Hole 516F). 
M. RENARD, G. RICHEBOIS, R. LÉTOLLE

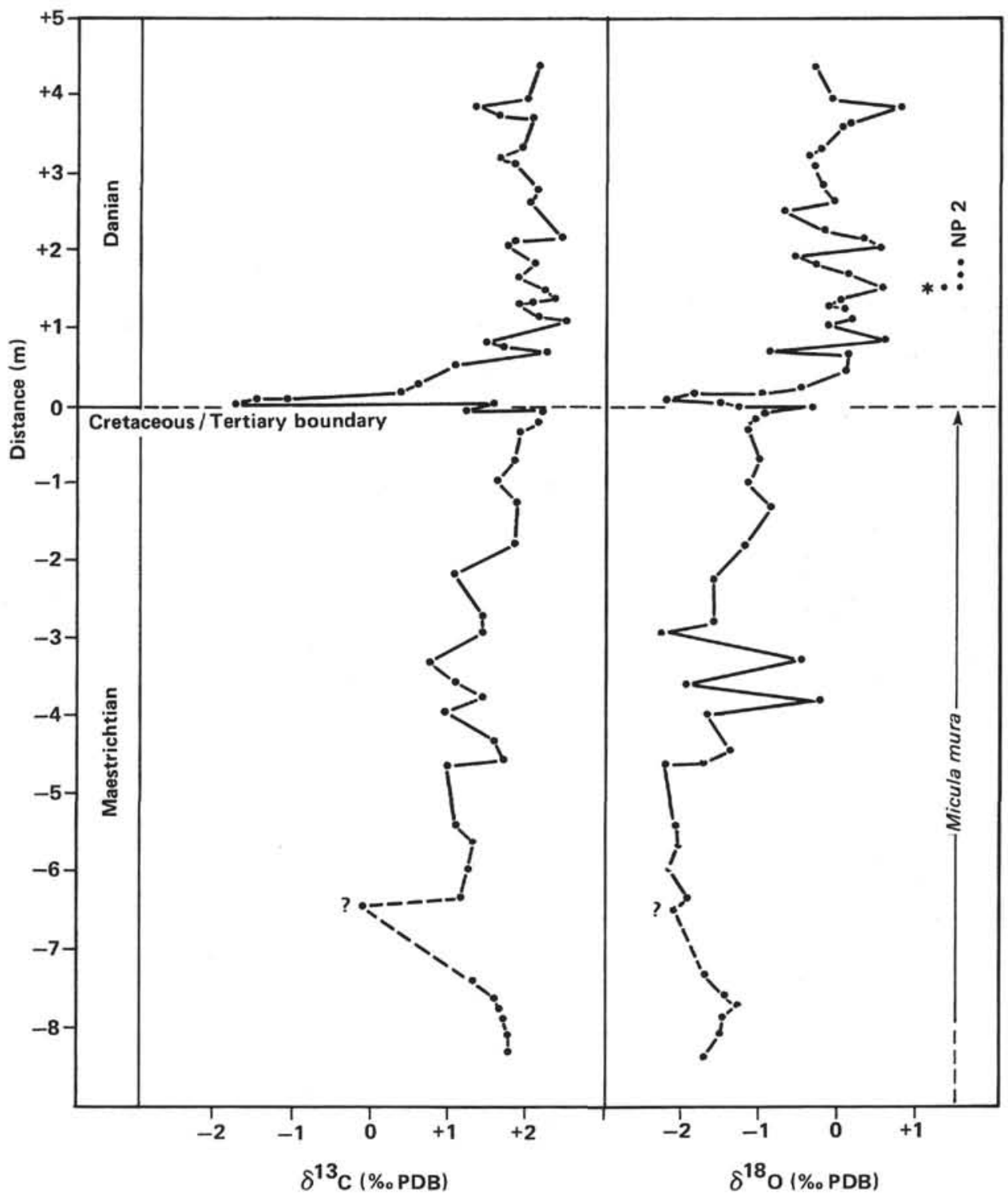

Figure 18. Stable isotope curves of bulk carbonate for Bidart outcrops (Biscaye, France) after Delacotte and Renard (unpublished data). 